\title{
SOBRE LA APLICACIÓN EN LA PRÁCTICA DEL MODELO CHILENO DE RECONOCIMIENTO Y EJECUCIÓN DE RESOLUCIONES EXTRANJERAS Y LA NECESIDAD DE SU REFORMA*
}

[About the Application in Practice, and Unavoidable Reform, of the Chilean Model of Recognition and Enforcement of Foreign Judgements]

\author{
Carlos Esplugues Mota* \\ Universidad de Valencia, España
}

\begin{abstract}
Resumen
El Derecho internacional privado chileno ofrece un reducido y disperso número de normas, poco elaboradas además. El artículo se centra en el punto del reconocimiento y ejecución de resoluciones judiciales y laudos arbitrales extranjeros, en especial con base en la práctica adoptada por la Corte Suprema desde 2000 hasta 2014. El resultado final del estudio pone en duda el modelo vigente y apunta hacia una reforma urgente de la normativa en materia de reconocimiento y ejecución de resolución judiciales extranjeras en Chile.

Palabras clave

Reconocimiento de sentencias extranjeras - Ejecución de sentencias extranjeras - Exequatur.
\end{abstract}

Abstract

The Chilean private international Law has a small and scattered, not quite developed, number of rules. This article focuses on the recognition and enforcement of foreign legal judgements and arbitration awards, especially based on the practice adopted by the Supreme Court from 2000 to 2014. The final result of this study questions the current model and aims at an urgent reform of the norms regarding the recognition and enforcement of foreign legal judgements in Chile.

\section{KEYWORDS}

Recognition of foreign judgements - Enforcement of foreign judgements Exequatur.

RECiBido el 31 de octubre y ACEPTADo el 22 de diciembre de 2014

* Artículo elaborado en el marco del proyecto I+D MINECO DER 2013-44749 Mediación, arbitraje y jurisdicción en el actual paradigma de justicia: integración, 'glocalización', Derecho público y ODR como alguno de sus retos y PROYECTO PROMETEO II/2014/081 (GV) ADR y Justicia.

** Catedrático de Derecho internacional privado de la Universidad de Valencia, España. Correo electrónico: carlos.esplugues@uv.es 


\section{EL INCREMENTO DE LAS RELACIONES PRIVADAS INTERNACIONALES EN UN MUNDO INTERRELACIONADO}

Vivimos en un mundo caracterizado por la movilidad y la interconexión. Le revolución tecnológica de las últimas décadas ha conducido a una situación sin parangón. Nunca antes habíamos sido testigos de un volumen similar de relaciones entre personas -físicas y jurídicas- pertenecientes a distintos Estados. Y nunca con anterioridad, además, estas relaciones se habían generado con la rapidez, constancia y habitualidad con que se manifiestan en nuestros días.

Frente a este fenómeno complejo y cambiante, la respuesta ofrecida por parte de los ordenamientos jurídicos de los distintos Estados viene caracterizada por dos factores claramente diferenciables. Por un lado, este conjunto de relaciones tienen lugar en un mundo que, si bien desde una perspectiva económica, e incluso social, aparece más integrado que nunca, desde un punto de vista jurídico sigue presentando un muy elevado grado de fraccionamiento: la actividad económica global que se refleja en un movimiento transfronterizo de personas, capitales y bienes como nunca antes se ha producido coexiste así con una pluralidad de ordenamientos jurídicos nacionales independientes y desconectados entre sí. Ciertamente puede hablarse de la existencia de procesos de codificación internacional, pero éstos ni cubren todos los sectores del ordenamiento jurídico ni cuentan con un similar grado de desarrollo en las distintas zonas geográficas del globo. Por otro lado, la respuesta que ofrecen los diversos legisladores nacionales a este fenómeno de la internacionalización de las relaciones privadas, en aquellas ocasiones en que se produce, no siempre es ni lo consciente, ni lo amplia, flexible o elaborada que requeriría un fenómeno tan complejo como es el de las relaciones jurídico-privadas internacionales.

Chile, como seguidamente veremos, constituye un buen ejemplo de ello. La opción adoptada desde hace décadas en favor de generar una economía dinámica y abierta al mundo, y que ha conducido, por ejemplo, a ser el único país iberoamericano miembro de la Organización para la Cooperación y el Desarrollo Económicos ${ }^{1}$ o determinado, un incremento notable del número de extranjeros viviendo en el territorio nacional ${ }^{2}$, no ha venido acompañada

${ }^{1}$ Véase: http://www.oecd.org/chile/adhesiondechilealaocde.htm [visitado el 15 de noviembre de 2014].,

${ }^{2}$ De acuerdo con el censo de 2012, un 2\% de la población de la República ha nacido fuera de Chile (339.536 personas), frente al 1.2\% de hace 11 años (véase: http://www. americaeconomia.com/politica-sociedad/sociedad/numero-de-inmigrantesresidentes-en-chile-casi-se-duplico-en-una-decada [visitado el 17 de octubre de 2014]. Por su parte, el Registro de chilenos en el exterior menciona en su última 
de la correlativa elaboración de un marco normativo claro que favorezca esta apertura. El legislador estatal, como otros muchos legisladores nacionales, no parece ser consciente de la trascendencia económica y social que el diseño de este marco normativo posee para la vida diaria de las empresas y de los particulares, ni de las ventajas y desventajas competitivas que su presencia o ausencia genera en todos aquellos que participan en cualquier actividad internacional, ya sea comercial o meramente particular.

La conjunción de estos factores, entre otros varios, afecta directamente a la continuidad de las relaciones jurídicas entabladas entre los particulares, incidiendo negativamente en sus expectativas jurídicas y personales, y se encuentra en la base misma de la existencia del Derecho internacional privado ${ }^{3}$.

La presencia en una concreta situación o relación jurídica de un elemento de extranjería y, a través de éste, su consiguiente vinculación con más de un ordenamiento jurídico, plantea directamente a las autoridades judiciales o extrajudiciales un conjunto de cuestiones que no se suscitan en aquellas ocasiones en que la situación o relación jurídica a debate se presenta vinculada exclusivamente con el ordenamiento jurídico de la propia autoridad. En este último caso el operador jurídico no necesita, en principio, cuestionarse acerca de la extensión y límites de la jurisdicción nacional y, por ende de su competencia (judicial internacional) para conocer del litigio, ni de cual sea la ley aplicable al fondo de la cuestión o cuestiones suscitadas. Algo que, por el contrario, sí acontece en aquellos supuestos en que se hace patente un elemento de extranjería ${ }^{4}$. Ello, lógicamente, genera un nivel de complejidad y dificultad inexistente en las situaciones vinculadas a un único ordenamiento

versión accesible (2005) que 857.781 chilenos viven fuera del territorio nacional (en torno a un 4,2\% de la población total del país, véase: Ministerio de Relaciones Exteriores/DICOEX, Chilenos en el exterior, Dónde viven, cuántos son y qué hacen los chilenos en el exterior, Santiago, 2005, p. 11 (disponible en: http://www. chilesomostodos.gov.cl/descargas/cat_view/50-registro-de-chilenos.html [visitado el 17 de octubre de 2014].

${ }^{3}$ Véase: Esplugues Mота, C., El Derecho internacional privado: caracteristicas generales, en Esplugues Mota, C. - Iglesias Buhigues, J. L. - Palao Moreno, G., Derecho internacional privado (8a edición, Valencia, Tirant lo Blanch, 2014), pp. 75-76; Garcimartin Alférez, F., Derecho internacional privado (Cizur Menor, Civitas - Thomson Reuters, 2012), pp. 31-32.

${ }^{4} \mathrm{Y}$ ello, dejando de lado la cuestión de la exigencia o no del carácter relevante del mencionado elemento. Al respecto, véase: la sentencia de la Corte Suprema de 28 de julio de 2008, considerando $3^{\circ}$ : “[...] Ahora bien, no todo elemento extranjero transforma el caso en internacional, sino que es menester que las consecuencias de los hechos demanden una reglamentación que corresponda a su carácter internacional. Por consiguiente, para que se trate de un auténtico caso de derecho internacional, ese elemento extranjero debe ser relevante, esto es, importante o significativo". 
jurídico, y exige de un tratamiento propio y diferenciado para éstas por parte del legislador y de los operadores jurídicos.

Las preguntas que se formula la autoridad judicial o extrajudicial nacional ante una situación con elementos de internacionalidad son coincidentes, de alguna manera, con las materias cubiertas por el propio Derecho internacional privado: en primer lugar, ante la constatación de que se está confrontando una situación con elementos de internacionalidad, se hace necesario preguntarse si una determinada autoridad cuenta, o no, con competencia judicial internacional para conocer de la cuestión ante ella suscitada ${ }^{5}$. Caso de ser así deberá plantearse seguidamente qué ley se aplicará a su resolución y, por último, que efectos producirá la eventual resolución que pueda dictar la autoridad en el extranjero y, viceversa, con qué nivel de eficacia contarán las decisiones emanadas de autoridades foráneas en nuestro país.

Nuestro artículo se centra en esta última dimensión, abordando la realidad del régimen jurídico existente en Chile en relación con el reconocimiento y ejecución de resoluciones judiciales en el territorio nacional con base en la práctica de éste. No pretendemos elaborar un estudio doctrinal más al uso, sino identificar, a partir de un análisis exhaustivo de toda la jurisprudencia de la Corte Suprema de Justicia en la materia desde 2000 hasta 2014, las claves sobre las que de forma fehaciente se articula el modelo chileno en su realidad práctica. El estudio de estos casi dos centenares de sentencias emanados de la Suprema Corte en estos catorce años nos permite concretar el funcionamiento real de las soluciones incorporadas en los artículos 242 ss. CPC. . y descifrar las grandes líneas interpretativas sobre las que éstos se asientan. Y a partir de todo ello, verificar si su conformación actual -tanto en el plano legislativo como en su plasmación práctica por la Corte Supremaes acorde con la realidad económica y social chilena, y si coadyuva, o no, a la satisfacción de las expectativas e intereses de las empresas y ciudadanos de Chile, y en Chile, al ofrecer una respuesta unidireccional, segura, cierta y eficaz a la problemática de la eficacia en la República de las resoluciones

${ }^{5}$ Sobre la interacción entre cada uno de estos niveles, considérese, FERNÁNDEZ Arroyo, D., Aspectos esenciales de la competencia judicial internacional en vistas de su reglamentación interamericana, en Llanos Mansilla, H. - Picand Albónico, E. (coordinadores), Estudios de derecho internacional. Libro homenaje al profesor Santiago Benadava (Santiago, Librotecnia, 2008), II, p. 118 ss.

${ }^{6}$ Véase la sentencia de la Corte Suprema de 28 de julio de 2008, considerando 3": "Que la doctrina nacional define el derecho internacional privado como la rama del derecho que tiene por objeto resolver acerca de las normas que se aplican y los tribunales que conocerán los asuntos con elementos internacionales relevantes; regular los efectos de las sentencias extranjeras y determinar la nacionalidad de las personas naturales y jurídicas y la condición jurídica de los extranjeros [...]". 
judiciales extranjeras. Lamentablemente, y como quedará aseverado a lo largo del texto, nuestra respuesta, la avanzamos ya, es todo menos positiva.

\section{LAS CLAVES DEL DERECHO INTERNACIONAL PRIVADO CHILENO}

El derecho internacional privado chileno cuenta con un carácter muy reducido de normas y no es especialmente elaborado en lo que a las soluciones recogidas en las mismas se refiere. A ello se une, además, su condición enormemente dispersa. Esta situación se reputa de todos los sectores que lo componen: tanto de las disposiciones sobre competencia judicial internacional, como sobre Derecho aplicable o en relación con el reconocimiento y ejecución de resoluciones judiciales y laudos arbitrales extranjeros.

Como punto de partida, el modelo chileno de derecho internacional privado se articula sobre una premisa clara: la vigencia en la República del Código de Derecho Internacional Privado ${ }^{7}$, que incorpora en el ordenamiento jurídico patrio a la llamada "Convención de derecho internacional privado" o "Código Bustamante", concluido en La Habana el 13 de febrero de $1928^{8}$. Sin embargo, estamos ante una premisa que parece carecer de solidez suficiente debido a la conjunción de una serie de factores de índole diversa.

i) En primer lugar, y si bien el Código cuenta con una voluntad de completud en cuanto a las materias por él cubiertas, su efectividad se ve reducida por el limitado ámbito de aplicación geográfico con que cuenta -algunos países Iberoamericanos-, amén de por el importante volumen de reservas que en su día generó el proceso de ratificación por los distintos Estados participantes en su elaboración.

ii) En segundo lugar, se pone en tela de juicio la validez y viabilidad de las soluciones recogidas en el texto, en muchas ocasiones -se dice- profundamente arcaicas y de difícil puesta en práctica, lo que añade un elemento adicional de tensión sobre el Código.

iii) Y por último, y lo que resulta mucho más relevante a efectos de la propia realidad chilena, a pesar de que el "Código Bustamante" cuenta aparentemente con plena aplicabilidad en Chile su vigencia efectiva se ve severamente limitada por el tenor de la reserva formulada por Chile en el momento de su ratificación. El gobierno chileno señaló en su día "[...] que ante el Derecho Chileno y con relación a los conflictos que se produzcan entre la legislación chilena y alguna extranjera, los preceptos de la legislación actual ofutura de Chile, prevalecerán sobre dicho Código, en caso de desacuerdo entre unos

${ }^{7}$ Código de Derecho Internacional Privado, Decreto N³74, del Ministerio de Relaciones Exteriores, de 10 de abril de 1934 (D.O. de 25 de abril de 1934).

${ }^{8}$ El "Código Bustamante" no fue ratificado en su día por Argentina, Uruguay, Paraguay, Colombia ni México. 
y otros". Esto es, la normativa chilena prevalecerá en caso de conflicto sobre la legislación convocada por las normas recogidas en el "Código Bustamante".

Si a todo ello le unimos un cierto desconocimiento por parte de los operadores jurídicos de lo que es y significa el Código y de sus soluciones, llegaremos a la conclusión de que esa imagen de un sistema -el chileno- lineal y claramente articulado sobre un texto amplio y general resulta más ficticia que real.

Todos estos datos que confluyen en el "Código Bustamante" - o Código de Derecho Internacional Privado en terminología chilena-, y especialmente la mencionada reserva formulada por Chile en el momento de su vinculación al mismo, unido a la tendencia de la Corte Suprema a hacer primar las soluciones de los textos internos -en nuestro caso, y en relación específicamente a la materia objeto del presente artículo, el Código de Procedimiento Civil-sobre el "Código Bustamante", otorgan al resto de fuentes de origen nacional un papel protagónico del que a primera vista, aparentemente, deberían carecer dada la presencia de dicho Código en nuestro ordenamiento jurídico. Sin embargo, la prevalencia de las normas de origen estatal sobre el texto del "Código Bustamante" (no sólo) en caso de desacuerdo entre éstas y las normas extranjeras convocadas a través del mismo, algo que no resulta en modo alguno inhabitual, insufla un hálito de vida a las soluciones recogidas, por ejemplo, en el Código Civil ${ }^{10}$, en el Código de Comercio ${ }^{11}$, en el Código de Procedimiento Civil' ${ }^{12}$, en la Ley N ${ }^{\circ}$ 4.808: Orgánica del Registro Civil, de 10 de febrero de $1930^{13}$, en la Ley $N^{\circ} 7.421$, de 9 de julio de 1943, en el Código Orgánico de Tribunales ${ }^{14}$, en la Ley $\mathrm{N}^{\circ}$ 18.046: Sobre sociedades anónimas $^{15}$, en la Ley $\mathrm{N}^{\circ}$ 19.620, de 5 de agosto de 1999: Que dicta normas sobre adopción de menores ${ }^{16}$, en la Ley $\mathrm{N}^{\circ} 19.947$, de 7 de mayo de 2004: De matrimonio civil, ${ }^{17}$ en la Ley $\mathrm{N}^{\circ}$ 19.971: Sobre arbitraje comercial internacional, de 10 de septiembre de 1994, en el Decreto $\mathrm{N}^{\circ} 172$, del Ministerio de Relaciones Exteriores, de 29 de julio de 1977, que establece el Reglamento

${ }^{9}$ Véase más abajo el cap. IV, $4 a$ ).

${ }^{10}$ Artículos 14, 16-18, 55-57, 60, 135 inciso $2^{\circ}$, 444, 482, 523, 604, 955, 977-998, $1012,1023,1027-1029,1050,1716,1723,2411$ y 2484.

${ }^{11}$ Artículos 113, 114, 214 inciso $4^{\circ}, 446$ inciso $9^{\circ}, 447,584,823,832,868,869$, 917, 931, 1096, 1098, 1211 y el antiguo libro IV ("De las Quiebras"), artículos 68, 69, 139 y 151.

${ }^{12}$ Artículos 76, 241-251, 347, 362, 411, 500-511 y 860.

${ }^{13}$ Artículos 4, 5, 8 y 16 de julio de

${ }^{14}$ Artículos 5, $\left.45 \mathrm{~g}\right), 116,149,405,420$ y 526.

${ }^{15}$ Artículos 16, 27 B, 69bis d) y 121-124.

${ }^{16}$ Artículos 5, 20, 30 y 31.

${ }^{17}$ Artículos 80-84 y artículo transitorio 2. 
Consular $^{18}$, o en el Decreto-ley $\mathrm{N}^{\circ}$ 2.349: Que establece normas sobre contratos internacionales para el sector público.

Este cuadro, complejo de por sí, se ve además acompañado de la presencia en el ordenamiento jurídico chileno de una serie de normas de origen convencional que complementan y en ocasiones modulan al anterior, y que técnicamente prevalecen sobre las normas de origen interno ${ }^{19}$. Por centrarnos en los Convenios sobre derecho internacional privado, y dejando de lado aquellos que refieren a sectores específicos como puede ser el transporte o los bienes inmateriales, se trataría de Convenios elaborados en el marco de la Conferencia de La Haya ${ }^{20}$, de la CIDIP ${ }^{21}$, del Mercosur ${ }^{22}$, de la UNCI$\mathrm{TRAL}^{23}$ o del Banco Mundial ${ }^{24}$. Convenios a los que Chile se ha vinculado

${ }^{18}$ Artículos 11,32 inciso $7^{\circ}, 36$ inciso $5^{\circ}, 47$ inciso $1^{\circ}, 53$ incisos $1^{\circ}$ y $5^{\circ}, 54$ incisos $1^{\circ}, 2^{\circ}$ y $3^{\circ}, 56$ incisos $2^{\circ}, 3^{\circ}$ y $8^{\circ}, 61,62$ inciso $1^{\circ}, 63,65,68,69,71-77,79-81,83-85,87$, 90-92 y capítulos $32^{\circ}$ y $33^{\circ}$.

${ }^{19}$ Véanse, por ejemplo, los artículos 839, 900, 979 ó 1096 CCom. Igualmente, y en relación con el contrato de transporte aéreo y la aplicación de los textos convencionales que vinculan a Chile en la materia, nótese la sentencia de la Corte Suprema de 11 de agosto de 2011.

${ }^{20} \mathrm{El}$ Convenio sobre los aspectos civiles de la sustracción internacional de menores, de 25 de octubre de 1980; y el Convenio sobre la protección de menores y la cooperación en materia de adopción internacional, de 29 de mayo de 1993.

${ }^{21}$ El Convenio sobre arbitraje comercial internacional, hecho en Panamá el 30 de enero de 1975; el Convenio sobre exhortos y cartas rogatorias, hecho en Panamá el 30 de enero de 1975; el Convenio sobre régimen legal de poderes para ser utilizados en el extranjero, hecho en Panamá el 30 de enero de 1975; el Convenio sobre recepción de pruebas en el extranjero, hecho en Panamá el 30 de enero de 1975; el Convenio sobre conflictos de leyes en materia de cheques, hecho en Panamá el 30 de enero de 1975; el Convenio sobre conflictos de leyes en materia de letras de cambio, pagarés y facturas, hecho en Panamá el 30 de enero de 1975; el Protocolo adicional a la Convención sobre exhortos o cartas rogatorias, hecho en Montevideo el 8 de mayo de 1979; el Convenio sobre prueba e información acerca del Derecho extranjero, hecho en Montevideo el 8 de mayo de 1979; el Convenio sobre conflictos de leyes en materia de cheques, hecho en Montevideo el 8 de mayo de 1979 o el Convenio sobre conflictos de leyes en materia de adopción de menores, hecho en La Paz, el 24 de mayo de 1984., Todos estos convenios son "interamericanos".

${ }^{22} \mathrm{El}$ "Acuerdo sobre arbitraje comercial internacional MERCOSUR", hecho en Buenos Aires el 23 de julio de 1998 y el Acuerdo de Cooperación y Asistencia Jurisdicción en Materia Civil, Comercial, Laboral y Administrativa entre los Estados partes del Mercosur y la República de Bolivia y la República de Chile, hecho en Buenos Aires el 5 de julio de 2002.

${ }^{23}$ El Convenio sobre el reconocimiento y la ejecución de las sentencias arbitrales extranjeras hecho en Nueva York el 10 de junio de 1958 y el Convenio sobre compraventa internacional de mercaderias, hecha en Viena el 11 de abril de 1980.

${ }^{24}$ "Convenio CIADI" (Washington, 1964). 
y que, por lo tanto, forman parte plena del ordenamiento jurídico nacional prevaleciendo sobre las disposiciones de origen interno.

Y a estos dos niveles normativos, por último, se une la eventual vigencia en sectores concretos de los denominados usos y prácticas del comercio internacional ${ }^{25}$, que resultan de especial interés en el ámbito del comercio internacional, y cuya naturaleza y valor ha sido abordado en alguna ocasión por la Corte Suprema de Chile ${ }^{26}$.

El resultado final es un marco normativo articulado sobre un Código de Derecho Internacional Privado dotado de una aparente voluntad de aplicabilidad general, que en la práctica queda subordina al mandato de las disposiciones nacionales, ya sean de origen interno o convencional, en cuantas ocasiones la norma convocada por el Código resulte contradictoria con lo dispuesto en el derecho patrio. Un modelo de crecimiento aluvial, carente de sistemática, cuyas soluciones son aisladas y no siempre suficientemente elaboradas. Y en el que la coexistencia de textos legales de origen, naturaleza y época diferentes necesariamente favorecerá la presencia de ciertas lagunas e incoherencias en su aplicación, sin que una interpretación integradora vía artículo 19 CC. parezca suficiente para dotarlo de la linealidad que requiere. Un modelo al que se une, además, ya lo hemos apuntado, un cierto desconocimiento de su existencia y contenido por parte de los operadores jurídicos patrios. Como seguidamente observaremos, todos estos datos, y los graves riesgos derivados de ellos, añadiríamos, se hacen especialmente patentes al analizar el modelo chileno de reconocimiento y ejecución de resoluciones judiciales extranjeras.

\section{El MODELO CHILENO DE RECONOCIMIENTO Y EJECUCIÓN DE RESOLUCIONES EXTRANJERAS}

\section{Eficacia en Chile de las resoluciones extranjeras: sus posibles niveles de eficacia.}

Al igual que ocurre con el resto del sistema de derecho internacional

${ }^{25}$ Considérese, por ejemplo, el artículo 584 CCom. en relación con el contrato de reaseguro y el artículo 9 del "Convenio de Viena" de 1980 sobre compraventa internacional de mercaderías ratificado en su día por Chile y que forma parte del ordenamiento jurídico nacional.

${ }^{26}$ Por ejemplo, la sentencia de la Corte Suprema de 22 de enero de 2008, en el que se suscita una cuestión relativa a los INCOTERMS, pero en los que no se aborda su validez jurídica, al referirse la cuestión objeto de análisis a la materia de competencia judicial internacional y la sentencia de la Corte Suprema de 25 de agosto de 2010, en la que sí se aborda -considerando 7- el valor de los usos y prácticas en la contratación internacional. 
privado patrio, el modelo chileno de reconocimiento y ejecución de resoluciones judiciales foráneas destaca por su no excesiva elaboración. El modelo se caracteriza, salvo en el caso concreto del arbitraje comercial internacional, por conjugar su articulación sobre un número reducido de preceptos del Código de Procedimiento Civil, con la habitual ausencia de textos convencionales ya sean bilaterales o multilaterales en la materia. De esta suerte, se limita a fijar con más o menos acierto las claves para el cumplimiento de las resoluciones foráneas en Chile, pero dejando sin especificar con claridad algunos extremos claves como qué se entienda por resolución extranjera, ni diferenciar entre reconocimiento y ejecución, ni especificar los efectos exactos que se derivan de su reconocimiento ni, tampoco, aquellos que puedan producir en Chile al margen de éste.

Como principio general, los documentos públicos extranjeros en cuanto integran actos y negocios jurídicos celebrados en el extranjero pueden producir en Chile todo un elenco de efectos de diversa gradación, dependientes, en última instancia, del tipo concreto de documento de que se trate. Dicha eficacia, lógicamente, viene subordinada a la satisfacción de ciertos requisitos de índole diversa - previsiblemente- recogidos por nuestra legislación.

Así, en cuanto documentos públicos que son pueden producir efectos probatorios, teniendo igualmente acceso ocasional a los registros públicos de nuestro país, los llamados efectos registrales. Junto a ello, los documentos públicos foráneos que cuenten con la condición de ejecutivos de acuerdo con la ley de su país de origen, son susceptibles de gozar en ciertas ocasiones de efectos ejecutivos en el territorio nacional. Esta última categoría de efectos aparece dotada de una dimensión marcadamente procesal, vinculada al régimen del reconocimiento y ejecución de resoluciones judiciales extranjeras; resoluciones que, a la postre, no dejan de ser documentos públicos extranjeros.

\section{Efectos documentales de la decisión extranjera.}

El documento público extranjero, en cuanto documento acreditativo de unos determinados hechos o situaciones con relevancia jurídica, es susceptible de generar el denominado efecto probatorio. Dicho tipo de efectos -que pueden tener una dimensión judicial y extrajudicial- se circunscriben al plano puramente documental, concretándose en la mera prueba del contenido del documento. Esta eficacia documental se admite de forma expresa por la doctrina chilena afirmando que, la sentencia extranjera, que en cuanto a su forma se ha ajustado a la legislación del país en que se dictó, constituye un instrumento público, "que da fe de los hechos que contiene en cuanto ha pasado a la vista del juez o tribunal que la dictó”27. Esta aceptación expresa es

${ }^{27}$ Monsalvez Müller, A., Del cumplimiento en Chile de resoluciones pronuncia- 
también realizada de forma aislada por la jurisprudencia de la Corte Suprema -"no sepuede desconocer que un fallo foráneo puede hacerse valer, sin necesidad de exequátur, como medio de prueba, valor que deriva del carácter auténtico del acto" 28 - Y viene taxativamente prevista en el artículo 420 inciso $5^{\circ}$ COT. donde se precisa con claridad el valor como documento público de "5. Los instrumentos otorgados en el extranjero, las transcripciones y las traducciones efectuadas por el intérprete oficial o los peritos nombrados al efecto por el juez competente y debidamente".

El texto puramente enunciativo del artículo 420 inciso $5^{\circ} \mathrm{COT}$. debe interpretarse de forma conjunta con el mandato del artículo $347 \mathrm{CPC}$., que exige su traducción, y del artículo 17 CC. en el que se aportan algunas claves importantes en relación con la forma de verificar la condición de documento público auténtico -en línea con la terminología usada en los artículos 1699 a 1701 CC.- del documento otorgado en el extranjero. Así, el primer párrafo del artículo 17 CC. determina la regulación de la forma de los instrumentos públicos por "la ley del país en que hayan sido otorgados". Señalando su segundo párrafo que "su autenticidad se probará según las reglas establecidas en el Código de Enjuiciamiento. La forma se refiere a las solemnidades externas, y la autenticidad al hecho de haber sido realmente otorgados y autorizados por laspersonas y de la manera que en los tales instrumentos se exprese". Esta última regla incorpora una referencia indirecta al mandato del artículo 345 CPC. ${ }^{29}$.

La solución alcanzada nada dice acerca del potencial control que el operador jurídico chileno pueda realizar sobre el contenido de dicho documento extranjero, limitándose a abordar la dimensión estrictamente formal de éste. Aún más importante que lo anterior, nada señala sobre los eventuales efectos - por ejemplos, probatorios- que el contenido del documento pueda producir en Chile, esto es sobre la dimensión sustantiva del documento foráneo. Si bien desde una perspectiva formal se acepta su equiparación con los documentos públicos chilenos y se determina cómo verificar su forma y autenticidad, nada se apunta acerca de su contenido, y sobre la manera en que se va a incardinar en la realidad jurídica chilena el hecho o situación jurídica relevante del que da cuenta dicho documento público extranjero, y los efectos que va a producir. Esta cuestión es objeto de controversia doctrinal. En la

das por tribunales extranjeros (Santiago, Andrés Bello, 1973), p. 63. En igual sentido, Guzmán Latorre, D., Tratado de Derecho internacional privado, Santiago, Editorial Jurídica de Chile, 2003, p. 569.

${ }^{28}$ La sentencia de la Corte Suprema de 9 de noviembre de 2006, considerando Duodécimo.

${ }^{29}$ En esta misma línea, Monsalvez Müller, A. (n. 27), pp. 62-63. Respecto de la interpretación de este precepto en relación con documentos extranjeros, nótese la sentencia de la Corte Suprema de 21 de enero de 2008, considerando Tercero. 
medida en que no se trata de reconocer el efecto de cosa juzgada se afirmaría la innecesaridad de someter la decisión extranjera al trámite del exequatur ${ }^{30}$.

La jurisprudencia chilena moderna existente en relación con este punto, por su parte, es escasísima e inconcluyente, por no decir inexistente ${ }^{31}$. Siendo necesario referirse a la práctica jurisprudencial de la primera mitad del siglo XX para encontrar algunos fallos, muy criticados por la doctrina al considerarse desmedida la referencia al exequatur, que respondieron afirmativamente a la solicitud de exequátur presentadas ante la Corte Suprema: en concreto las decisiones de 2 de abril de 1949, en la que concede el exequatur a una "sentencia extranjera que reconoce la calidad de heredero del causante e interesados residentes en el pais de origen, ya que no se trata de cumplir ese fallo en Chile, sino que sirve de antecedente probatorio para la petición de posesión efectiva que aquellos se proponen iniciar en Chile"32.

\section{Efectos registrales de la decisión extranjera.}

En ciertas ocasiones, los documentos públicos extranjeros pueden incardinar afirmaciones o constataciones susceptibles de ejecución impropia; esto es, documentos cuya ejecución queda agotada con el acceso al correspondiente registro público del documento. Se habla así de la eficacia registral del documento. El volumen de efectos derivados de este eventual acceso a un Registro público chileno es superior en trascendencia a los generados por la utilización del documento público extranjero como un mero elemento de acreditación de unos determinados hechos o circunstancias -el denominado "efecto probatorio" al que se ha hecho referencia anteriormente-.

Sin embargo, aun siendo importante, esta dimensión de efectos no viene regulada en la normativa chilena de origen estatal. $\mathrm{Si}$, en cambio, se recoge su existencia, que no se regula, en la normativa chilena de origen convencional .

i) Si bien el Código de Derecho Internacional Privado, en su artículo 423, al abordar la eficacia de las resoluciones extranjeras, menciona de forma genérica que éstas “tendrá(n) fuerza y podrá(n) ejecutarse" en los Estados parte si reúnen las condiciones previstas en el Código. El título $10^{\circ}$ refiere expresamente a la "Ejecución de sentencias dictadas por tribunales extranjeros"

${ }^{30}$ Monsalvez Müller, A. (n. 27), pp. 65 ss. La razón estriba en el hecho de que cuando se invoca una sentencia extranjera solamente como documento, no se están invocando los pronunciamientos de derecho del juez extranjero (GUZMán LATORRE, D. (n. 27), p. 571. Se trata, tan sólo, de unos hechos cuyo valor no obliga al juez chileno. El juez chileno debería, así, apreciarlos libremente de acuerdo con la normativa chilena sobre prueba.

${ }^{31}$ Véase la sentencia de la Corte Suprema de 19 de marzo de 2008.

${ }^{32}$ Revista T. 38, sec. $1^{\text {a }}$, p. 29, citada por Monsalvez Müller, A., cit. (n. 27), p. 66. 
y, dentro de éste, sus artículos 424 y 426 hace mención a la solicitud de la "ejecución de la sentencia" o al "juez o tribunal a quien se pida la ejecución", respectivamente. Sin embargo, el artículo 431 CDIP. asume que hay sentencias extranjeras que, a pesar de someterse a exequatur no pueden ser "ejecutables" por sus pronunciamientos, produciendo "los efectos de cosa juzgada si reúnen las condiciones que a ese fin determina este Código, salvo las relativas a su ejecución".

ii) Por su parte, el artículo 249 CPC. . habla genéricamente de "[...] los asuntos de jurisdicción no contenciosa", precisando una solución diferenciada en relación con el procedimiento de exequatur de los "casos de jurisdicción contenciosa". Nada más.

El resultado final de esta posición plantea dudas de carácter dogmático y de economía procesal. Con respecto a las primeras, se obvia el hecho de que las sentencias extranjeras pueden ser meramente declarativas o pueden perseguir finalidades distintas de las puramente ejecutivas, como en este nivel de efectos ocurre. En estos casos, el operador jurídico chileno, no necesariamente el juez, debería proceder a valorar la decisión extranjera en el ámbito del mero reconocimiento de la misma. Sin embargo, y de acuerdo con la práctica de la Corte Suprema , para lograr la eficacia registral de tales decisiones se exige el cumplimiento de las condiciones establecidas para la ejecución -o exequatur-, esto es, para el otorgamiento de fuerza ejecutiva a unas decisiones que carecen de ella en sentido estricto. Buenos ejemplos de esto lo constituyen las decisiones extranjeras que modifican el apellido de una persona $a^{33}$, o sobre concesión de tutela ${ }^{34}$ o curatela ${ }^{35}$, o incluso, las decisiones en materia de adopción, ${ }^{36}$ decisiones resultantes de un expediente de jurisdicción voluntaria. Como decimos, todas ellas se ven sometidas al régimen general del exequátur a pesar de no ser susceptibles de ejecución propia. Significativamente, esta posición parece contar con respaldo doctrinal en Chile ${ }^{37}$.

${ }^{33}$ Véanse las sentencias de la Corte Suprema de 16 de septiembre de 2002; de 3 de julio de 2003; de 12 de octubre de 2004 o de 28 de enero de 2008.

${ }^{34}$ Véase la sentencia de la Corte Suprema de 20 de diciembre de 2005, que concede el exequátur.

${ }^{35}$ Véase la sentencia de la Corte Suprema de 24 de noviembre de 2010, que concede el exequátur.

${ }^{36}$ Véanse las sentencias de la Corte Suprema de 15 de enero de 2002; de 5 de enero de 2009; de 13 de octubre de 2011; de 13 de enero de 2012; de 19 de marzo de 2012; de 24 de junio de 2013 y de 22 de enero de 2014 todas las cuales otorgan el exequátur. Y, del mismo tribunal, los fallos de 17 de octubre de 2000 y de 20 de junio de 2002 , que lo deniega por contrariar la ley chilena al tratarse en ambos casos de una adopción de persona mayor, circunstancia no prevista en Chile.

${ }^{37} \mathrm{Al}$ respecto, Guzmán Latorre, D., cit. (n. 27), p. 567. 
Junto a ello, en segundo lugar, esta opción supone imponer una carga adicional sobre el ciudadano que se ve obligado a acudir a la Corte Suprema de Justicia para el reconocimiento de unas sentencias que no van a contar técnicamente con una ejecución en sentido estricto, con todos los costes y tiempo que este hecho les genera a ellos y al propio sistema judicial chileno.

\section{Eficacia ejecutiva de las decisiones extranjeras.}

Por último, las sentencias foráneas pueden ser tratadas ante los tribunales chilenos como auténticas sentencias dotadas de fuerza ejecutiva en su país de origen, que buscan ser homologadas a través del reconocimiento, y posteriormente ejecutadas como tales sentencias, en Chile. La Corte Suprema no duda en afirmar que el exequátur "materialmente consiste en nuestro país, en la decisión de la Corte Suprema que, luego de sustanciar el procedimiento contradictorio respectivo, procede a revisar las exigencias legales y sin entrar a estudiar en detalle el fondo de la cuestión controvertida y materia del fallo que se pide cumplir, otorga autorización o pronunciamiento favorable a la sentencia extranjera que lo resuelve, con el objeto de otorgarle la fuerza ejecutiva de la que carece y reconocerle los mismos efectos que los fallos expedidos por jueces nacionales, lo que permitirá se la pueda cumplir mediante el procedimiento y ante el tribunal competente" ${ }^{38}$. No estamos, pues, ante "una instancia en la que corresponda debatir nuevamente el fondo del asunto resuelto en la sentencia cuya autorización de cumplimiento en Chile se solicita" 39 , o ante "un procedimiento para rever un juicio llevado a cabo en el extranjero: sólo se trata de determinar si una sentencia extranjera puede o no cumplirse en Chile"40.

a) Las nociones de "reconocimiento" y "ejecución" de las decisiones extranjeras. A través de la mención al reconocimiento y ejecución de una sentencia foránea se engloban dos realidades diferentes ${ }^{41}$.

Por un lado, el reconocimiento es el acto por el que un Estado otorga en su territorio a una resolución judicial extranjera los efectos procesales

${ }^{38}$ Véase la sentencia de la sentencia de la Corte Suprema de 10 de julio de 2008, considerando $2^{\circ}$. En idéntico sentido, Corte Suprema de 25 de marzo de 2008, considerando $3^{\circ}$; de 11 de mayo de 2009 , considerando $3^{\circ}$ o de 8 de noviembre de 2011 , considerando $1^{\circ}$.

${ }^{39}$ Corte Suprema, 8 de noviembre de 2011, considerando $6^{\circ}$.

${ }^{40}$ Corte Suprema , 24 de enero de 2005, considerando $6^{\circ}$.

${ }^{41}$ Véanse: Iglesias Buhigues, J. L., Eficacia extraterritorial de sentencias y documentos públicos extranjeros: el reconocimiento y ejecución de resoluciones judiciales extranjeras y documentos públicos con fuerza ejecutiva, en Esplugues Mota, C. - Iglesias Buhigues, J. L. - Palao Moreno, G., cit. (n. 3), pp. 190-192; García Martín Alférez, F., Derecho internacional privado, cit. (n. 3), p. 259; Virgós Soriano, M. - Garcimartin Alférez, F., Derecho procesal civil internacional. Litigación internacional ( $2^{\text {a }}$ edición, Cizur Menor, Civitas - Thomson, 2007), p. 541. 
que le atribuye el Derecho del Estado cuyos tribunales dictaron dicha resolución. Ello implica que mediante el reconocimiento se admiten en Chile los efectos declarativos y, junto a estos, se reconoce el valor probatorio de la resolución extranjera y su efecto de cosa juzgada material, con el alcance y los límites establecidos por el derecho del Estado de origen: la resolución pasa a entenderse como dictada por la autoridad del Estado requerido, y las partes no pueden volver a plantear ante sus tribunales la disputa resuelta por la resolución foránea ahora reconocida.

Por su parte, la ejecución -o exequátur-, es el acto por el que un Estado dota en su territorio, a una resolución extranjera, de fuerza ejecutiva. Esto es, la convierte en título ejecutivo. La concesión del exequatur permite obtener, en el Estado requerido y de acuerdo con el Derecho de éste, la ejecución forzosa, si fuere preciso, de la resolución dictada en el Estado de origen.

Esta dualidad de conceptos, como seguidamente veremos, no se recogen en el Código de Procedimiento Civil donde exclusivamente se hace referencia a la ejecución, esto es, al exequátur. Por su parte, si bien no han sido tradicionalmente asumidos por la doctrina patria ${ }^{42}$, sí que aparece crecientemente reflejados en la doctrina chilena ${ }^{43}$. A fecha de hoy, empero, se sigue tendiendo a diferenciar entre fuerza de cosa juzgada y efecto ejecutivo de la sentencia extranjera, aunque en forma incoherente y desordenada, en cuanto ambas son referidas a la concesión del exequátur a la decisión extranjera ${ }^{44}$, o el procedimiento de exequátur se ve calificado como "juicio de reconocimiento" 45 .

A pesar de lo anterior, ambas nociones no resultan ajenas a nuestra realidad legislativa, estando explícitamente presentes en la realidad jurídica chilena. En concreto, en otros textos legales referidos a la eficacia en Chile de sentencias extranjeras ${ }^{46}$, y de laudos arbitrales foráneos. Así, la "Ley de

${ }^{42} \mathrm{Al}$ respecto, Monsalvez Müller, A., cit. (n. 27), pp. 69 ss., quien, luego, significativamente en su obra Derecho internacional privado. Parte general (Santiago, Universidad Sek, 2005) dedica el apartado $2^{\circ}$ de su capítulo V al reconocimiento y ejecución en Chile de sentencias extranjeras (p. 302), aunque seguidamente habla genéricamente del "sistema chileno de cumplimiento de sentencias extranjeras" (p. 305). Por su parte, Guzmán LATORRe, D., cit. (n. 27), p. 565, habla del exequátur llamado también juicio de reconocimiento o procedimiento de delibación [...] trámite que inviste a la sentencia extranjera de los mismos efectos que la sentencia nacional, cuando ella cumple con ciertos requisitos superficiales, [...]".

${ }^{43}$ Así, por ejemplo, García PUJOL, I., Cumplimiento de sentencias extranjeras en Chile: alejándose del régimen de reciprocidad legal, en Llanos Mansilla, H. - PICAND Albónico, E. (coordinadores), cit. (n. 5), II, pp. 209 y 210.

${ }^{44}$ Guzmán Latorre, D., cit. (n. 27), p. 571; García Pujol, I., cit. (n. 43), p. 210.

${ }^{45}$ Guzmán Latorre, D., cit. (n. 27), p. 572.

${ }^{46}$ En concreto, el Acuerdo de cooperación y asistencia jurisdicción en materia civil, 
Arbitraje” de 2004, en su artículo 35.1, incorpora una nítida diferenciación entre estas dos realidades conceptuales: "Un laudo arbitral, cualquiera que sea el país en que se haya dictado, será reconocido como vinculante $y$, tras la presentación de una petición por escrito al tribunal competente, será ejecutado en conformidad con las disposiciones de este articulo y del articulo $36 " 47$. Por su parte, la nueva Ley de matrimonio civil de 2004 refiere genéricamente al reconocimiento de las decisiones extranjeras. Así lo hace la rúbrica de su capítulo $8^{\circ}$ : "De la ley aplicable y del reconocimiento de las sentencias extranjeras", y así se recoge en su artículo 83, al regular la forma en que las "sentencias de divorcio y nulidad de matrimonio dictadas por tribunales extranjeros serán reconocidas en Chile [...] “.

Sin embargo, y a pesar de ello, la jurisprudencia de la Corte Suprema que aborda la eficacia en Chile de las resoluciones judiciales extranjeras no parece deslindar con claridad ambas nociones, combinando en sus decisiones menciones a ambas realidades de forma indistinta. Así, la jurisprudencia de la Corte Suprema de Chile al analizar - no en demasiados casos $-{ }^{48}$ el significado, razón de ser y función del "exequátur" señala que éste constituye “[...] un juicio de reco n ocimien to ${ }^{49}$ en el que el tribunal competente comprueba la concurrencia de una serie de requisitos, expidiendo, a su término, la sentencia de exequátur, en la que se reconoce a un fallo extranjero los efectos propios de una sentencia nacional" 50 . Su objeto es "[...] que las resoluciones dictadas por tribunales extranjeros tengan la misma fuerza que si se bubieren dictado por tribunales chilenos" 1 , constituyendo "una revisión ineludible de toda resolución dictada por un tribunal extranjero que se pida cumplir en Chile" 52 .

b) Naturaleza y función del exequátur. Todolo dicho hasta el momento, y tal como hemos señalado con anterioridad, resultaría referible tanto del reconocimiento de una resolución extranjera como, eventualmente, de la ejecución-exequátur a través de la cual la sentencia extranjera homologada se ve atribuida fuerza ejecutiva en Chile. Mas, como hemos avanzado ya, la

comercial, laboral y administrativa entre los Estados partes del Mercosur y la República de Bolivia y la República de Chile, cuyo capítulo $5^{\circ}$ lleva por rúbrica "Reconocimiento y ejecución de sentencias y laudos arbitrales" y en cuyo articulado se plasma esta distinción.

${ }^{47}$ También en el plano convencional se recoge esta diferenciación. Así ocurre, por ejemplo, en los artículos 4 y 5 de la Convención sobre arbitraje comercial internacional de 1975.

${ }^{48}$ De hecho, las sentencias que lo hacen tienden a reproducir de forma mimética idéntico texto.

${ }^{49}$ Destacado del autor.

${ }^{50}$ Corte Suprema, 29 de mayo de 2014, considerando $4^{\circ}$.

${ }^{51}$ Corte Suprema, 8 de noviembre de 2011, considerando $5^{\circ}$.

${ }^{52}$ Corte Suprema, 5 de julio de 2000, considerando $2^{\circ}$. 
Corte Suprema no deslinda ambos conceptos con precisión. De hecho esta última dimensión referida es escasamente tratada como tal en la jurisprudencia de la Corte Suprema. De nuevo se vuelve al uso de afirmaciones genéricas: "El exequátur es necesario para que la sentencia extranjera tenga valor de cosa juzgada fuera de los limites del pais en que ha sido dictada. La resolución foránea por emanarde un poder público extranjero, sin el juicio previo de reconocimiento, no es más que un hecho y, por lo tanto, ningún efecto produce, es decir, carece de fuerza ejecutiva y de autoridad de cosa juzgada" ${ }^{33}$. El exequátur, añade, permite "[...] la globalización del cumplimiento de sentencias dictadas dentro de distintos ordenamientos jurídicos, evitando que las declaraciones de derechos y las exigencias en materia de cumplimiento de obligaciones no queden solo en esa etapa declarativa, sino que cumplan electivamente sus fines" $"$.

En todo caso, y a pesar del cierto grado de desenfoque que acompaña a la jurisprudencia de la Corte Suprema a la hora de afrontar la figura del exequátur, de ella se deriva una idea esencial con vistas a fijar el significado y función de la institución, y que es, además, compartida por la doctrina chilena ${ }^{55}$. La Corte Suprema deja clara que la revisión que implica el procedimiento de exequatur de la resolución extranjera es meramente formal, no sustantivo. La aparentemente taxativa referencia que realiza en algún momento la Corte Suprema a la "revisión ineludible" ${ }^{56}$ de la resolución extranjera por los tribunales chilenos viene, así, matizada por ella misma, al afirmar que a través del exequátur, la Corte Suprema tras "sustanciar el procedimiento contradictorio respectivo, procede a revisar las exigencias legales y sin entrar a estudiar en detalle el fondo de la cuestión controvertida en el juicio respectivo, otorga autorización o pronunciamiento favorable a la sentencia extranjera que lo resuelve, con el objeto de otorgarle la fuerza ejecutiva de la que carece y reconocerle los mismos efectos que los fallos expedidos porjueces nacionales, lo quepermitirá se la pueda cumplir mediante el procedimiento y ante el tribunal competente" 57 .

Esta idea de la no revisión del fondo de la resolución foránea es reiterada de forma constante por la Corte Suprema señalando que el exequátur no da pie "[...] en ningún caso a revisar en detalle lo que fue la controversia ni la justicia o injusticia intrinseca contenida en la resolución" 58 , siendo que "la finalidad

${ }^{53}$ Corte Suprema, 9 de noviembre de 2006, considerando $5^{\circ}$.

${ }^{54}$ Corte de Apelaciones de Santiago, 8 de agosto de 2011, considerando $10^{\circ}$.

${ }^{55} \mathrm{Al}$ respecto, GuZmán Latorre, D., cit. (n. 27), p. 565.

${ }^{56}$ Corte Suprema, 5 de julio de 2000, considerando $2^{\circ}$.

${ }^{57}$ Corte Suprema, 14 de mayo de 2007 , considerando $7^{\circ} ; 21$ de enero de 2008 , considerando $6^{\circ} ; 31$ de enero de 2011 , considerando $1^{\circ}$; de 8 de noviembre de 2011 , considerando $1^{\circ}$; o de 29 de mayo de 2014 , considerando $4^{\circ}$.

${ }^{58}$ Corte Suprema de 8 de noviembre de 2011 , considerando $3^{\circ}$. En esta misma línea está la sentencia de la Corte Suprema de 14 de mayo de 2007, considerando $6^{\circ}$. 
del procedimiento de exequátur, de acuerdo con el principio de la "regularidad internacional de los fallos", es verificar el cumplimiento de ciertos requisitos minimos, sin que de manera alguna constituya una instancia de revisión de lo alli resuelto; [...]"59. Lamentablemente, y como posteriormente veremos, este principio lejos de quedar nítido al verse proyectado en la práctica resulta mayoritariamente conculcado por la propia Corte Suprema de Justicia que, al amparo del artículo 245 CPC., no duda en entrar a conocer de forma sistemática del contenido de la decisión extranjera cuya eficacia en Chile se pretende, haciendo depender su decisión en múltiples ocasiones de este juicio de valor.

c) Objeto del exequátur: las sentencias extranjeras. Elobjetodel exequátur es una sentencia extranjera, entendida ésta como "decisión legítima del juez sobre la causa controvertida en su tribunal" ${ }^{\prime 60}$. La pregunta siguiente sería, lógicamente: ¿Y cuáles de estas sentencias extranjeras requieren ser objeto de exequátur? La doctrina chilena tiende a responder que "todas las resoluciones pronunciadas por tribunales extranjeros de cualquier naturaleza, ya sean ordinarios, arbitrales o especiales, sobre cualquier materia que traten de ser cumplidos en Chile, y que impongan la ejecución o cumplimiento de una obligación"61.

El Código de Procedimiento Civil y demás textos nacionales y convencionales susceptibles de ser aplicados en este ámbito utilizan de forma indistinta diversos vocablos al aproximar el objeto del exequátur. Así, el Código de Procedimiento Civil en sus artículos 242 ss. se refiere genéricamente a "resoluciones extranjeras". Algo que también ocurre en el Acuerdo de cooperación $y$ asistencia jurisdicción en materia civil, comercial, laboral y administrativa entre los Estados partes del Mercosur y la República de Bolivia y la República de Chile -artículo 18 ss.-. Mientras que, por su parte, los artículos 423 ss. CDIP. hablan indistintamente de "sentencias" -artículos 423, 424, 430, 431 y 433 - y de ejecutoria -artículo 429-62.

La Corte Suprema ha terciado en esta cuestión exigiendo en su sentencia de 14 de mayo de 2007 que la sentencia extranjera "tenga carácter de tal, que efectivamente haya sido pronunciada por un tribunal del Estado requirente y que revisado por las instancias superiores no haya presentado reparos en sus

${ }^{59}$ Corte Suprema, 8 de noviembre de 2011, considerando $3^{\circ}$.

${ }^{60}$ Monsalvez Müller, A., cit. (n. 27), p. 20.

${ }^{61}$ Hamilton, E., Solución de conflictos de leyes y jurisdicción en Chile (Santiago, Editorial Jurídica de Chile, 1966), p. 395.

${ }^{62} \mathrm{Al}$ respecto, y con una posición más restrictiva, aparentemente limitada a las sentencias, véase: GuZmán LATORRe, D., cit. (n. 27), p. 587. 
formas, e incluso, presentándolos, hayan sido corregidos, de manera tal que permita su ejecución en ese pais, si fuere del caso"63.

Pero la Corte refiere a la dimensión formal de la decisión extranjera, subsistiendo la cuestión decisiva de determinar de qué hablamos al referirnos a sentencia o resolución extranjera ${ }^{64}$. Ciertamente el término resolución extranjera es más amplio que el de sentencia y permitiría incluir dentro del mismo todo tipo de resolución emanada de un tribunal extranjero, incluyendo las transacciones judiciales ${ }^{65}$. Sin embargo, se trata de una cuestión que no parece haber sido abordada como tal por la jurisprudencia patria.

Como tampoco lo ha sido, de forma amplia, la cuestión de la naturaleza de la sentencia cuya eficacia se pretende en Chile. De si es necesario que sea firme -no susceptible de ulterior recurso- o basta con que tenga la condición de definitiva -susceptible de recurso-. No existe respuesta concluyente al respecto. El artículo $431 \mathrm{CDIP}$. exige la firmeza de las resoluciones extranjeras, pero lo hace respecto de una categoría muy concreta de ellas: aquellas que no son susceptibles de ejecución en sentido estricto. La jurisprudencia de la Corte Suprema, por su parte, se ha planteado de forma incidental esta cuestión en su sentencia de 28 de diciembre de 2000 en la que utiliza como argumento para denegar la ejecución solicitada la ausencia de carácter definitivo de la decisión extranjera cuyo exequátur se solicita: "Que del mérito de los antecedentes reseñados, aparece que la sentencia dictada por el tribunal extranjero no tiene carácter definitivo, puesto que contiene un acuerdo provisional y programático, que debería completarse por acuerdo de los interesados; y este acuerdo definitivo no es otro que el pactado y aprobado por el tribunal nacional; $[\ldots]]^{\prime 66}$. La cuestión ha sido igualmente tratada de forma indirecta en la Corte Suprema de 31 de julio de 2000, en la que se ventila la solicitud de exequatur respecto de una resolución extranjera de medidas cautelares. Una decisión, por su propia naturaleza, definitiva que no firme. Lamentablemente, la Corte Suprema deniega el exequatur sin afrontar la cuestión de la naturaleza de la decisión extranjera, amparándose sin más en la necesidad

${ }^{63}$ Considerando $17^{\circ}$.

${ }^{64}$ Véase el cap. IV , 2,1, a) ii), en relación con la interpretación del artículo 83 inciso $3^{\circ}$ de la Ley $\mathrm{N}^{\circ} 19.947$ que impide el reconocimiento de decisiones extranjeras de divorcio que "no haya sido declarado por resolución judicial".

${ }^{65}$ La sentencia de la Corte Suprema de 31 de julio de 2000 entiende que el mandato de los artículos 242 ss. CPC. Atañe a "toda suerte de resoluciones judiciales dictadas fuera de nuestras fronteras" (considerando $6^{\circ}$ ), pero se refiere no tanto a la naturaleza de las resoluciones cuya eficacia se pretende, como a la necesidad de que todas las decisiones extranjeras pasen por el trámite del exequátur para producir efectos en Chile.

${ }^{66}$ Considerando $3^{\circ}$. 
de obtener el exequátur de la decisión con base en la cual se dicta esta orden de embargo ${ }^{67}$.

d) Exequátur y exequátur parcial. La concesión del exequátur implica otorgar fuerza ejecutiva y autoridad de cosa juzgada a la sentencia foránea en los términos fijados por la decisión de concesión emanada de la Corte Suprema. No sólo será factible la concesión de un exequátur parcial ${ }^{68}$, sino que la eficacia vendrá limitada por la decisión de concesión. De esta suerte, por ejemplo, la jurisprudencia de la Corte Suprema admite de forma expresa que el reconocimiento de una decisión foránea de divorcio puede circunscribirse a la admisión de la ruptura del vínculo, pero no a los pactos económicos de los cónyuges respecto de los bienes habidos en el matrimonio ${ }^{69}$, o a la decisión contenida en la sentencia en relación con el cuidado personal de los hijos de las partes y no al divorcio, dado que el matrimonio no se encontraba inscrito en Chile ${ }^{70}$.

\section{REGÍMENES DE RECONOCIMIENTO Y EJECUCIÓN DE RESOLUCIONES EXTRANJERAS EN CHILE}

\section{Introducción.}

Las resoluciones judiciales foráneas carecieron de eficacia en Chile en los primeros años de la independencia ${ }^{71}$. Esta situación, tal como reconoce en su jurisprudencia la Corte Suprema de Chile ${ }^{72}$ se vio alterada a partir de la promulgación de la Ley $\mathrm{N}^{\circ} 1.552$, de 28 de agosto de 1902, que aprobó el Código de Procedimiento Civil, incorporando los preceptos actualmente vigentes en la materia ${ }^{73}$.

${ }^{67}$ Considerandos $4^{\circ}$ y $5^{\circ}$.

${ }^{68}$ Tanto en lo referente al petitum como a las personas frente a las que se puede invocar la decisión extranjera. $\mathrm{Al}$ respecto, nótense las sentencias de la Corte Suprema de 18 de diciembre de 2003; de 21 de enero de 2008, considerando Decimoquinto; de 18 de diciembre de 2003; de 19 de diciembre de 2006.

${ }^{69}$ Véase la sentencia de la Corte Suprema de 9 de noviembre de 2006, considerando $6^{\circ}$.

${ }^{70}$ Véase la sentencia de la Corte Suprema de 17 de junio de 2013, considerando $4^{\circ}$.

${ }^{71} \mathrm{El}$ artículo V del Reglamento Constitucional de 26 de octubre de 1812 disponía expresamente que: "Ningún decreto, providencia u orden, que emane de cualquier autoridad o tribunales de fuera del Territorio de Chile, tendrá efecto alguno; y los que intentaren darles valor, serán castigados como reos de Estado". Al respecto, GUZMÁn LATORRE, D., cit. (n. 27), p. 577.

${ }^{72}$ Véanse las sentencias de la Corte Suprema de 14 de mayo de 2007, considerando $7^{\circ}$; de 11 de mayo de 2009 , considerando $4^{\circ}$; de 31 de enero de 2011 , considerando $2^{\circ}$ o de 8 de noviembre de 2011 , considerando $2^{\circ}$. En todas ellas se refiere de forma mimética a la existencia en el plano comparado de diversos sistemas para el cumplimiento de las decisiones extranjeras.

${ }^{73}$ En cuyo "Mensaje" se lee: "La ejecución de las sentencias da lugar a dificultades 
El régimen chileno de reconocimiento y ejecución de "resoluciones pronunciadas por tribunales extranjeros" $"$ viene articulado sobre el mandato del artículo 423 CDIP., del Acuerdo de cooperación y asistencia jurisdicción en materia civil, comercial, laboral y administrativa entre los Estados partes del Mercosur y la República de Bolivia y la República de Chile, y de los artículos 242 a 251 CPC. Dado el limitado ámbito de aplicación geográfica del Código de Derecho Internacional Privado y del "Acuerdo del Mercosur", en la práctica son las disposiciones del Código de Procedimiento Civil-especialmente su artículo 245- las que cuentan con una condición preferente. De hecho, la jurisprudencia de la Corte Suprema atribuye una naturaleza expansiva al $C o ́-$ digo de Procedimiento Civil, tendiendo a identificar el modelo exclusivamente con los preceptos recogidos en éste ${ }^{75}$. Y atribuyendo un carácter marginal al mandato del artículo 242 CPC., y a la referencia que a través del mismo se realiza a los dos textos convencionales que vinculan a Chile en esta materia ${ }^{76}$.

El sistema diseñado en el Código de Procedimiento Civil aparece dotado de un orden jerárquico -la jurisprudencia se refiere a él, como modelo "en cascada" ${ }^{77}$ articulado sobre la coexistencia de tres distintos regímenes de reconocimiento y ejecución de resoluciones -tanto judiciales como arbitrales $-{ }^{78}$ extranjeras: el régimen convencional, el de reciprocidad y el de condiciones. En palabras de la Corte Suprema, los regímenes de "reciprocidad convencional", de "reciprocidad legal o interpretativa" y, por último, en ausencia de los anteriores, de "regularidad internacional" 7 . Cada uno de ellos se aplica de forma subsidiaria al anterior ${ }^{80}$. La inaplicabilidad del artículo

que se ha tratado de subsanar, especialmente en lo relativo a las que emanan de tribunales extranjeros, los tratados, la reciprocidad y, en último término, los principios de natural equidad, son las bases sobre que descansan estas disposiciones".

${ }^{74}$ Título $20^{\circ}$, De la ejecución de las resoluciones, numeral 2.

${ }^{75}$ Véanse las sentencia de la Corte Suprema de 31 de enero de 2011, considerando $2^{\circ}$ o de 8 de noviembre de 2011 , considerando $2^{\circ}$.

${ }^{76}$ Corte Suprema, 17 de enero de 2006, considerando $2^{\circ}$.

${ }^{77}$ Corte Suprema, 14 de mayo de 2007 , considerando $8^{\circ}$ o de 8 de noviembre de 2011, considerando $3^{\circ}$.

${ }^{78} \mathrm{El}$ artículo 246 CPC. dice: "Las reglas de los artículos precedentes son aplicables a las resoluciones expedidas por jueces árbitros. En este caso se hará constar su autenticidad $y$ eficacia por el visto-bueno u otro signo de aprobación emanado de un tribunal superior ordinario del pais donde se haya dictado el fallo".

${ }^{79}$ Corte Suprema, 14 de agosto de 2012, considerando $1^{\circ}$ DEG.

80 “[...] un sistema en cascada, en el que, en primer término, se atiende a los tratados existentes o de reciprocidad convencional y, a continuación, el de la reciprocidad legal o interpretativa. En ausencia de antecedentes que permitan determinar tales parámetros para reconocer los efectos que se prevé para cada caso, pasa a regir el sistema moderno o de la regularidad internacional, para lo cual esta Corte debe examinar las sentencias extranjeras con el objeto de decidir si ellas cumplen con los requisitos estatuidos en el artículo 245 
242 CPC. -en el que se incluye lo que podíamos calificar reproduciendo a la doctrina española, el régimen convencional- lleva, de acuerdo con el taxativo tenor del artículo 243 CPC. a la aplicación del régimen de reciprocidad, positiva -artículo 243 CPC.- y negativa -artículo 244 CPC.-. Y únicamente en defecto de cualquiera de las tres soluciones anteriores -" $E n$ los casos en que no pueda aplicarse ninguno de los tres artículos precedentes [...]"-, se procedería a tomar en consideración el tercero de los regímenes de reconocimiento previstos, el llamado régimen de condiciones recogido en el artículo 245 CPC. ${ }^{81}$.

El modelo chileno, al igual que ocurre en otros países iberoamericanos, parece tomar como ejemplo el tenor de los artículos 951 ss. de la Ley de Enjuiciamiento Civil de 1881, que sigue vigente en este punto en España, en el que se reproducen igualmente estos tres regímenes de reconocimiento y ejecución de resoluciones foráneas ${ }^{82}$. Precisamente, al igual que ocurre en España con la práctica del modelo, la jerarquía entre los tres regímenes no es tan clara, viéndose notablemente matizada en la práctica.

\section{El modelo convencional.}

El régimen convencional viene recogido en el artículo $242 \mathrm{CPC}$. El precepto afirma que las "[...] resoluciones pronunciadas en país extranjero tendrán en Chile la fuerza que les concedan los tratados respectivos; $y$ para su ejecución se seguirán los procedimientos que establezca la ley chilena, en cuanto no aparezcan modificadospor dichos tratados". Dos ideas básicas se desprenden directamente de la lectura del artículo:

$1^{\circ}$ En primer lugar, el precepto reconoce de forma expresa la prelación en esta materia, de lo dispuesto en los posibles convenios que vinculen a Chile en este ámbito, ya sean de naturaleza multilateral o bilateral. En la práctica se trata más de una declaración de principios que de una realidad, al menos respecto de las decisiones judiciales - no tanto de las arbitrales- extranjeras ${ }^{83}$.

del citado cuerpo legal [...]" (Corte Suprema, 31 de enero de 2011, considerando $3^{\circ}$, o de 8 de noviembre de 2011, considerando $3^{\circ}$ ).

${ }^{81}$ Véase, a modo de ejemplo, y entre otras muchas, la sentencia de la Corte Suprema de 2 de julio de 2014.

${ }^{82} \mathrm{Al}$ respecto, véase: Esplugues Mota, C., Una aproximación internacional privatista al nuevo código de procedimiento civil de Bolivia, de 2013, en Revista Boliviana de Derecho, 18 (2014), pp. 53 ss.

${ }^{83}$ Cuestión distinta es el reconocimiento de laudos arbitrales extranjeros, donde existe un volumen amplio de convenios bilaterales que vinculan a Chile. Así, los laudos arbitrales extranjeros se verán reconocidos en Chile a través de lo dispuesto en el "Convenio de Nueva York” de 1958 sobre reconocimiento de sentencias arbitrales extranjeras que al amparo de su artículo I,3, y dado que Chile no hizo reserva o manifestación alguna al respecto en el momento de vincularse al mismo, cuenta con aplicación universal 
Y ello, dado que en relación con las resoluciones judiciales extranjeras, y ante la inexistencia de convenios bilaterales que vinculen a Chile en este sector, la mención a los tratados supone principalmente una referencia al ya mencionado "Código Bustamante" de 1928, convertido en Código de Derecho Internacional Privado por el Decreto $\mathrm{N}^{\circ} 374$, del Ministerio de Relaciones Exteriores, de 10 de abril de $1934^{84}$. Un Código que, tal como ha quedado apuntado, cuenta con un ámbito de aplicación geográfico y material limitado. Y, en menor medida, al Acuerdo de cooperación y asistencia jurisdicción en materia civil, comercial, laboral y administrativa entre los Estados partes del Mercosur y la República de Bolivia y la República de Chile. En aquellos casos, los más, en que no se aplique el Código de Derecho Internacional Privado o el "Acuerdo de Mercosur" habrá de estarse a lo dispuesto en el artículo 243 ss. CPC.

a) El Código de Derecho Internacional Privado afirma en su artículo 423 que: "Toda sentencia civil o contencioso-administrativa dictada en uno de los Estados contratantes, tendrá fuerza y podrá ejecutarse en los demás si reúne las siguientes condiciones:/ 1. Que tenga competencia para conocer del asunto y juzgarlo, de acuerdo con las reglas de este Código, el juez o tribunal que la haya dictado;/ 2. Que las partes hayan sido citadas personalmente o por su representante legal, para el juicio;/ 3. Que el fallo no contravenga el orden público o el derecho público del pais en que quiere ejecutarse;/ 4. Que sea ejecutorio en el Estado en que se dicte;/ 5. Que se traduzca autorizadamente por un funcionario o intérprete oficial del Estado en que ha de ejecutarse si alli fuere distinto el idioma empleado;/ 6. Que el documento en que conste reúna los requisitos necesarios para ser considerado como auténtico en el Estado de que proceda, y los que requiera para que haga fe la legislación del Estado en que se aspira a cumplir la sentencia".

De acuerdo con el mandato del artículo 242 CPC., los artículos 243 ss. CPC. sólo operarán en aquellas ocasiones en que no exista tratado que vincule a Chile en la materia: consecuentemente, "si de acuerdo a lo prescrito por un tratado una sentencia extranjera tiene valor en nuestro país, esta sentencia

en el país. Esto es, se aplica tanto a los laudos provenientes de Estados parte en el "Convenio" como de aquellos que no lo son. En aquello que pueda resultar más favorable que el "Convenio de Nueva York", y de acuerdo al artículo VII de este texto convencional, se aplicarán también la Convención interamericana sobre arbitraje comercial internacional, hecha en Panamá el 30 de enero de 1975, y el Acuerdo sobre arbitraje comercial internacional entre el Mercosur, la República de Bolivia y la República de Chile, hecho en Buenos Aires el 23 de julio de 1998. Véase, al respecto: Corte Suprema, 11 de enero de 2007; 15 de septiembre de 2008; 21 de junio de 2010; de 8 de septiembre de 2011 o de 28 de marzo de 2012.

${ }^{84}$ Véase la nota 7. 
no necesita reunir los requisitos señalados por el artículo 245 CPC. [...] para ejecutarse en Chile" ${ }^{85}$. Al compás del tenor del artículo 242 CPC. prevalecería, por lo tanto, el artículo 423 CDIP. sobre lo dispuesto en el Código de Procedimiento Civil, en todas aquellas ocasiones en que la decisión foránea cuyo exequatur se pretende entre en el ámbito de aplicación del Código. Llamativamente, sin embargo, la práctica de la Corte Suprema desatiende esta regla de forma radical. El precepto ha sido aplicado en algunos supuestos aislados de forma lineal por la Corte Suprema ${ }^{86}$. Mas en otros, significativamente, el mandato del artículo 423 CDOP. ha sido directamente obviado, viéndose afectado por la interpretación que la jurisprudencia chilena realiza de los artículos 242 ss. CPC.

i) Así, con carácter general, la referencia que a través del artículo 242 CPC. se realiza al "Código Bustamante" se ha convertido, en algunos casos, en la práctica del Alto Tribunal, en un análisis de los requisitos previstos en el artículo 245 CPC. $^{87}$, o de estos últimos de consuno con los del artículo 423 CDIP. ${ }^{88}$. Requisitos, los previstos en el Código de Procedimiento Civil, que, como seguidamente veremos, no son en modo alguno coincidentes con los previstos en el mencionado artículo 423 CDIP., a pesar de que la Corte Suprema menciona que se trata de "requisitos que resultan análogos a los que establece el artículo 245 del Código de Procedimiento Civil"89. El resultado final choca radicalmente con el artículo $242 \mathrm{CPC}$. que reconoce la prioridad del modelo convencional sobre el estatal, tal como recuerda la propia Corte Suprema ${ }^{90}$.

Esta situación encuentra, además, un elemento adicional de singularidad en relación con las sentencias extranjeras de divorcio. En ellas, y a través de

${ }^{85}$ GuZmán Latorre, D., cit. (n. 27), p. 578.

${ }^{86}$ Corte Suprema, 27 de septiembre de 2005 o 1 de julio de 2010.

${ }^{87}$ Así, el considerando $4^{\circ}$ de la sentencia de la Corte Suprema de 5 de diciembre de 2012 precisa: "Que la sentencia que se trata de cumplir en Chile aparece dictada en uno de los casos que la legislación nacional contempla sobre la curaduría, de manera que no contraviene las leyes de la Republica, ni tampoco se opone a la jurisdicción nacional, en la medida que significa dotar a quien no puede dirigirse a si misma o administrar competentemente sus negocios, y que no se encuentra bajo potestad alguna de la debida protección, de suerte, pues, que como en la especie concurren cada una de las circunstancias exigidas en el articulo 423 del Código de Bustamante, en relación con el artículo 242 del Código de Procedimiento Civil, reseñadas en el fundamento segundo de esta sentencia, corresponde acoger la solicitud en estudio" (espaciado nuestro).

${ }^{88}$ Véanse las sentencias de la Corte Suprema de 18 de abril de 2011, considerando $4^{\circ}$; de 29 de septiembre de 2011, considerando $5^{\circ}$ o de 9 de noviembre de 2011, considerando $6^{\circ}$ en las que se valoran conjuntamente los requisitos previstos en los artículos 423 CDIP. y 245 CPC. .

${ }^{89}$ Corte Suprema, 9 de noviembre de 2011, considerando $3^{\circ}$.

${ }^{90}$ Corte Suprema, 27 de septiembre de 2005, considerando $2^{\circ}$ o 18 de abril de 2011. 
una referencia al artículo 242 CPC., se incide en la aplicabilidad del "Código Bustamante" y se reproduce el tenor del artículo 423 CDIP. ${ }^{91}$. Sin embargo, lejos de valorarse la sentencia extranjera con base en el proceso, se procede a aplicar de forma maximalista el mandato del artículo 83 de la nueva Ley de matrimonio civil $^{92}$, para concluir con una nueva mención al Código de Derecho Internacional Privado ${ }^{93}$.

ii) Reflejo de esta obviedad es, igualmente, la interpretación que ha realizado la Corte Suprema de la no contrariedad con el orden público nacional previsto en el artículo 423 inciso $3^{\circ} \mathrm{CDIP}$. El orden público internacional viene conformado por el conjunto de valores y principios que constituyen la base misma del ordenamiento jurídico nacional. En tal sentido no viene positivizado, debiendo ser fijado su contenido por el operador jurídico caso por caso. Y además cuenta con una naturaleza territorial, relativa y temporal. La valoración de la situación se realiza no de acuerdo con el orden público existente en el momento en que se produjo la situación o se dictó la sentencia, sino con los principios que conforman el orden público en el momento en que se busca la eficacia de dicha resolución extranjera ${ }^{94}$. Ello implicaría, en relación con la espinosa cuestión del divorcio vincular, que aquellas sentencias extranjeras, independientemente del momento en que fueron dictadas, que disuelven por divorcio el vínculo que une a un chileno, cuya eficacia se pretende ahora no fueran consideradas como contrarias al orden público nacional. Dado que en este momento, el divorcio constituye una institución recogida en el ordenamiento chileno y, por lo tanto, la indisolubilidad del vínculo matrimonial por divorcio no forma parte del orden público internacional de Chile.

Frente a esta argumentación, que debería dar como consecuencia directa la concesión del exequátur al amparo del Código de Derecho Internacional

${ }^{91}$ Corte Suprema, 18 de agosto de 2008, considerando $2^{\circ}$.

${ }^{92}$ Corte Suprema, 18 de agosto de 2008 , considerandos $4^{\circ}$ a $7^{\circ}$.

${ }^{93}$ Corte Suprema 18 de agosto de 2008, considerando $8^{\circ}$ : “Que, en relación con la materia, es útil anotar que el inciso segundo del aludido articulo 83 de la Ley $N^{\circ} 19.947$, dispone que 'las sentencias de divorcio y nulidad de matrimonio dictadas por tribunales extranjeros serán reconocidas en Chile conforme a las reglas generales que establece el Código de Procedimiento Civil', de suerte, pues, que como en la especie concurren las circunstancias exigidas en el artículo 426 del Código de Bustamante, reseñadas en el fundamento segundo de esta sentencia, en relación con la norma del artículo 242 del Código de Enjuiciamiento Civil, corresponde acoger la solicitud en estudio. En similar sentido, la sentencia de la Corte Suprema de 29 de septiembre de 2008, considerando $8^{\circ}$.

${ }^{94}$ Sobre el contenido y naturaleza del orden público, véase: Esplugues Mota, C., La determinación del Derecho aplicable a las situaciones jurídico-privadas internacionales: aplicación práctica de la norma de conflicto, en Esplugues Mota, C. - Iglesias Buhigues, J. L. - Palao Moreno, G., cit. (n. 3), pp. 294-297. 
Privado, a las sentencias extranjeras de divorcio incardinables en su ámbito de aplicación, al no ser entenderse contrarias al orden público internacional chileno. La Corte Suprema adopta una posición mucho más restrictiva y formalista, en nada favorable a los intereses personales de las partes, plenamente en línea con la mantenida al aplicar el artículo 245 inciso $1^{\circ} \mathrm{CPC}$. en este sector. ${ }^{95}$ Esta rígida interpretación, en la que como posteriormente veremos ${ }^{96}$ no se valora la eventual contrariedad con el orden público chileno, sino la adecuación estricta con la normativa de la República, ha llevado a denegar el exequatur a una decisión extranjera de separación, que no implica la ruptura del vínculo matrimonial, en un momento en que en Chile ya se admite plenamente el divorcio -que sí supone tal ruptura amparándose en el tenor de la nueva Ley de matrimonio civil ${ }^{77} \mathrm{y}$ en sus disposiciones transitorias ${ }^{98}$. Una ley que, sin embargo y curiosamente, recoge en su artículo 83 inciso $3^{\circ}$ una mención expresa a la contrariedad con el orden público chileno: "En ningún caso tendrá valor en Chile el divorcio que no haya sido declarado por resolución judicial o que de otra manera se oponga al orden público chileno".

Consecuentemente, la Corte Suprema en línea estricta con el mandato del artículo 245 inciso $1^{\circ} \mathrm{CPC}$. y desatendiendo el artículo 423 inciso $3^{\circ} \mathrm{CDIP}$., en vez de valorar la contrariedad con los principios esenciales del modelo existentes en el momento de solicitarse el exequatur en Chile, procede sin más a considerar el tenor y mandatos de la Ley $\mathrm{N}^{\circ} 19.94$, de 17 de mayo de 2004, de Matrimonio Civil señalando que la concesión del exequátur, en este caso, a una decisión cubana de mayo de 2004, contravendría el mandato del artículo 83 ,inciso $1^{\circ}$, de la mencionada norma legal ${ }^{99}$. Entendiéndose no cubierta por la regla del inciso primero del artículo 2 transitorio de dicha Ley y, por lo tanto, denegándose el exequátur. Este mismo proceso de valoración de la contrariedad con el orden público previsto en el artículo 423 inciso $3^{\circ}$ CDIP. a través de la extrapolación del proceso interpretativo seguido en relación con el artículo 245 inciso $1^{\circ} \mathrm{CPC}$., cuyo tenor y filosofía difiere del recogido en el mencionado precepto del "Código Bustamante", se reitera por la Corte Suprema en su jurisprudencia en la materia. Incluso en aquellas ocasiones en que finalmente sí se otorga el exequátur ${ }^{100}$. 2008.

${ }^{95}$ Véase, a modo de ejemplo la sentencia de la Corte Suprema de 15 de julio de

${ }^{96}$ Véase el cap. IV, $4 a$ ).

${ }^{97}$ Corte Suprema, 28 de junio de 2006, considerando $6^{\circ}$.

${ }^{98}$ Ibíd., considerandos $8^{\circ}$ y $9^{\circ}$.

${ }^{99}$ Que dice: "El divorcio estará sujeto a la ley aplicable a la relación matrimonial al momento de interponerse la acción”. Véase, al respecto, la sentencia de la Corte Suprema de 22 de noviembre de 2006, considerando $5^{\circ}$.

${ }^{100}$ Así, por ejemplo, la sentencia de la Corte Suprema de 1 de abril de 2009. En este 
b) La mención al Código de Derecho Internacional Privado viene acompañada de forma muy marginal por una referencia al Acuerdo de cooperación y asistencia jurisdicción en materia civil, comercial, laboral y administrativa entre los Estados partes del Mercosur y la República de Bolivia y la República de Chile, que fue promulgado por el Decreto $\mathrm{N}^{\circ} 71$, del Ministerio de Relaciones Exteriores ${ }^{101}$. El Acuerdo incorpora un capítulo $5^{\circ}$, intitulado "Reconocimiento y ejecución de sentencias y laudos arbitrales", y su artículo 20 precisa que: "Las sentencias y los laudos arbitrales a que se refiere el articulo precedente, tendrán eficacia extraterritorial en los Estados Partes si reúnen las siguientes condiciones:/ a) que vengan revestidos de las formalidades externas necesarias para que sean considerados auténticos en el Estado de donde proceden; / b) que éstos y los documentos anexos que fueren necesarios, estén debidamente traducidos al idioma oficial del Estado en el que se solicita su reconocimiento y ejecución; / c) que éstos emanen de un órgano jurisdiccional o arbitral competente, según las normas del Estado requerido sobre jurisdicción internacional;/ d) que la parte contra la que se pretende ejecutar la decisión haya sido debidamente citada y se haya garantizado el ejercicio de su derecho de defensa; / e) que la decisión tenga fuerza de cosa juzgada y/o ejecutoria en el Estado en el que fue dictada; / f) que no contrarien manifiestamente los principios de orden público del Estado en el que se solicitare el reconocimiento y/o la ejecución./ Los requisitos de los literales a), c), d), e) yf) deben surgir del testimonio de la sentencia o del laudo arbitral".

El precepto ha sido aplicado en una ocasión por la Corte Suprema, en su Sentencia de 23 de mayo de $2013^{102}$, con un resultado más que sorprendente. Tras apuntar su vigencia y analizar sus soluciones, el Alto Tribunal procede a reproducir el artículo 24 del mencionado Convenio ${ }^{103}$ que precisa, en línea con lo que es habitual en el plano comparado, que el procedimiento para el reconocimiento y ejecución se fija y regula por las leyes procesales del Estado en el que se solicita. A partir de aquí la Corte Suprema procede a aplicar en relación con el cumplimiento y ejecución de la sentencia en lo que concierne al procedimiento para el reconocimiento y ejecución de las decisiones extranjeras "las disposiciones del Código de Procedimiento Civil, normativa de orden público, que debe ser observada a cabalidad"104_. En concreto, los artículos 438 y 439 CPC. referidps a la ejecución de las sentencias

caso no se hace referencia al Código de Procedimiento Civil, pero sí se valora la decisión foránea en relación con los mandatos de la Ley $\mathrm{N}^{\circ} 19.947$.

${ }^{101}$ D.O. de 7 de agosto de 2009.

${ }^{102}$ Corte Suprema, 23 de mayo de 2013, considerando $2^{\circ}$.

${ }_{103}$ "Los procedimientos, incluso la competencia de los respectivos órganos jurisdiccionales, a los efectos de reconocimiento y ejecución de las sentencias o de los laudos arbitrales, se regirán por la ley del Estado requerido".

${ }^{104}$ Corte Suprema, 23 de mayo de 2013, considerando $3^{\circ}$. 
nacionales, o de aquellas sentencias extranjeras que una vez homologadas se han visto ya dotadas de fuerza ejecutiva (algo que en este caso no ocurría todavía). La Corte Suprema obvia la exigencia de homologación de una decisión foránea exigida por los artículos 242 CPC., y procede sin más a aplicar las disposiciones del Código de Procedimiento Civil relativas a la ejecución de las decisiones nacionales que exigen el carácter líquido o liquidable de la obligación de que dé cuenta la decisión. Y es precisamente amparándose en la ausencia de dicha naturaleza liquida o liquidable de la obligación recogida en la sentencia extranjera por lo que el Alto Tribunal procede a denegar el exequatur solicitado ${ }^{105}$. La referencia al Acuerdo deviene, así, puramente nominal y para nada son analizados los motivos recogidos en su artículo 20.

c) Existen significativamente algunos casos en los que la Corte Suprema hace referencia a textos convencionales que técnicamente no versan sobre reconocimiento y ejecución. La cuestión se suscita, con especial claridad, en materia de alimentos. Si bien existen supuestos en los que la Corte Suprema aplica de forma correcta la Convención sobre obtención de alimentos en el extranjero, de 20 de junio de 1956, y que fue ratificada por Chile el 23 de enero de $1961^{106}$. En otros, la Corte Suprema parece no tener clara cuál es la naturaleza del mencionado Convenio - prevista con claridad en su artículo $1-$ y tiende a combinar referencias equívocas a la Convención a la hora de conceder el exequatur. En unas ocasiones a través de la mención para justificar que la acción sobre la que versa la sentencia cuyo exequátur se pretende está prevista en el ordenamiento chileno ${ }^{107}$, y en otras, sin más, como una de las bases para la concesión del exequátur al amparo del artículo 245 CPC. ${ }^{108}$.

$2^{\circ}$ En segundo lugar, y tal como hemos avanzado ya, el artículo 242 sólo contempla, en sentido estricto, la "ejecución” en la República de resoluciones pronunciadas fuera de Chile. No el "reconocimiento" de aquéllas. En esta línea, el artículo 247 ss. CPC. refieren siempre a la ejecución al abordar el procedimiento de exequátur. De esta suerte, el artículo 247 CPC. precisa que la resolución extranjera "que se trate de ejecutar" se presentará en copia

${ }^{105}$ Ibíd., considerandos $5^{\circ}$ y $6^{\circ}$.

${ }^{106}$ Véase la sentencia de la Corte Suprema de 23 de diciembre de 2004 considerando $5^{\circ}$.

${ }^{107}$ Corte Suprema, 2 de abril de 2007 , considerandos $2^{\circ}$ y $4^{\circ}$.

${ }^{108}$ Ya ello a pesar que se reconoce que no existe "tratado en la materia con la nación de que procede la resolución que aprobó el avenimiento [...], respecto a la fuerza de las resoluciones pronunciadas en pais extranjero" (Corte Suprema, 5 de diciembre de 2001, considerando $6^{\circ}$ ). 
legalizada ante la Corte Suprema. Y, el artículo 248 CPC., por su parte, habla de la "parte contra la que se pide la ejecución"109.

Esta opción da como resultado algo ya señalado en relación con el efecto registral de las decisiones foráneas. Existen resoluciones meramente declarativas, no susceptibles de ejecución en sentido estricto o que persiguen finalidades distintas de las puramente ejecutivas. A todas ellas se les somete, con independencia de su naturaleza y objeto, al régimen de la ejecución o exequatur: esto es, al previsto para dotarlas de fuerza ejecutiva en Chile.

También el procedimiento de exequatur recogido en el Código de Derecho Internacional Privado, texto al que dirige el mandato del artículo 242 CPC., se asienta sobre la figura de la ejecución de la sentencia extranjera, sin distinguir entre reconocimiento y ejecución: así dentro del Título $10^{\circ}$, dedicado a la "Ejecución de sentencias dictadas por tribunales extranjeros", se refiere en sus artículos 424 y 426 a la "ejecución de la sentencia" o al "juez o tribunal a quien se pida la ejecución", respectivamente. Sin embargo, este punto de partida se flexibiliza un tanto en su artículo 431, al asumir el propio Código que hay sentencias extranjeras que, a pesar de someterse a exequátur -recordemos, atribución de fuerza ejecutiva a las mismas- pueden no ser "ejecutables" por sus pronunciamientos, produciendo "los efectos de cosa juzgada si reúnen las condiciones que a ese fin determina este Código, salvo las relativas a su ejecución”.

\section{El modelo de reciprocidad.}

Los artículos 243 y 244 CPC. afirman que en ausencia de convenios y tratados internacionales que vinculen a Chile en la materia habrá de estarse al principio de reciprocidad, tanto positiva como negativa. Así, en aquellos supuestos en que no existan convenios concluidos con el Estado del que proceda la resolución que se pretende reconocer susceptibles de ser aplicados "se les dará la misma fuerza que en ella se dé a los fallos pronunciados en Chile". Y, correlativamente, señala el artículo 244 CPC., si la resolución "procede de un pais en que no se da cumplimiento a los fallos de los tribunales chilenos, no tendrá fuerza en Chile" ${ }^{110}$.

Una lectura lineal de ambos preceptos daría como resultado una respuesta conclusiva; nada quedaría fuera de las dos opciones planteadas en

${ }^{109}$ Ciertamente, el artículo 251 CPC. dice genéricamente: "Mandada cumplir una resolución pronunciada en país extranjero, se pedirá su ejecución [...]”. La obligación de cumplimiento puede efectivamente englobar aquellos supuestos de ejecución impropia, pero todo apunta a una redacción en la que se contrapone el reconocimiento de fuerza ejecutiva a la sentencia extranjera, y su solicitud de ejecución en caso de incumplimiento voluntario.

${ }^{110}$ Sobre las bases históricas del modelo de reciprocidad, nótese, García Pujol, I., cit. (n. 43), p. 211. 
ausencia de textos internacionales aplicables. Las sentencias pronunciadas en países extranjeros, tendrán la misma fuerza en el territorio chileno que la que en ellos se diere a las ejecutorias dictadas en Chile. Si, por el contrario, la sentencia procede de un país cuyos tribunales deniegan el cumplimiento de las resoluciones emanadas de Tribunales chilenos, carecerán de fuerza en la República. En la práctica, empero, el modelo dista mucho de ser así.

La prueba de la reciprocidad, "sea en su forma negativa o positiva, legalo de hecho corresponde al que lo alega", tal como reconoce la propia Corte Suprema $^{111}$. Por una parte, la reciprocidad positiva no suele probarse. Su prueba es dificultosa y muy costosa, y las condiciones que se pueden exigir en el país extranjero para la eficacia de las resoluciones judiciales chilenas que haría factible al juego de la reciprocidad pueden ser mínimas o excesivas, algo que en ninguno de los dos casos resulta aceptable. Por su parte, la verificación de la reciprocidad negativa daría lugar a la denegación del exequátur. Reciprocidad negativa que para la Corte Suprema implica probar "que a los fallos emanados e tribunales chilenos se les niegue sistemáticamente fuerza obligatoria" ${ }^{112}$. La Corte Suprema de Justicia, atendiendo las importantes consecuencias que se derivan de la apreciación de la reciprocidad negativa incide especialmente en el hecho de la necesidad de acreditar "que por mandato legal o reiteración sistemática de decisiones de los tribunales competentes para decidir la materia, se niega fuerza a las sentencias expedidas por los tribunales chilenos, por este solo antecedente. Es más, parte de la doctrina nacional exige que la falta de reciprocidad emane de una disposición legal, por cuanto otorga mayor certeza y no se crean dudas [...]"113. De otra forma, y tal como ha ocurrido en alguna ocasión, la Corte Suprema va a ser reluctante a estimar esta reciprocidad negativa ${ }^{114}$.

${ }^{111}$ Corte Suprema, 21 de marzo de 2001, considerando $5^{\circ}$; u 8 de octubre de 2003, considerando $3^{\circ}$.

${ }^{112}$ Corte Suprema, 11 de mayo de 2009, considerando $6^{\circ}$.

$11{ }^{1[. . .]}$ Al efecto se puede citar que en nuestro pais existe, en la jurisprudencia de esta Corte, múltiples oportunidades que se ha negado el pase a sentencias expedidas por tribunales argentinos y bolivianos, por diferentes razones, pero, en ningún caso, se podrá sostener que dicha negativa ha tenido por fundamento que ello aconteció en razón del Estado del cual provienen las resoluciones, pues en otros casos particulares se ha reconocido la posibilidad de ejecutarse en nuestro territorio a sentencias de tribunales de esos paises" (Corte Suprema, 11 de mayo de 2009, considerando $6^{\circ}$ ).

${ }^{114}$ Así, por ejemplo, la sentencia de la Corte Suprema de 14 de mayo de 2007, considerando $9^{\circ}$. El tribunal resalta que es imprescindible probar la denegación sistemática de la fuerza obligatoria a las resoluciones chilenas en el país de origen de la decisión cuyo exequátur se solicita, algo que en este supuesto se entendió que no quedaba "probado en autos, pues en el informe con que se trata de acreditar lo anterior y la sentencia que se acompaña al expediente sólo permite precisar que en tales casos no se ha dado autorización para la ejecución en Estados Unidos de los fallos que se mencionan, que están expedidos en un ordenamiento que adhiere al 'case law'. Más aún, es público y notorio que incluso las re- 
Lo anterior conduce en la práctica al juego del régimen de condiciones o de "regularidad internacional" previsto en el artículo 245 CPC. que, lejos de ser residual y subordinado a los dos anteriores, se convierte en el régimen general.

\section{El modelo de "regularidad internacional"115.}

El colofón de "esta regulación 'en cascada', en que de un sistema debepasarse a otro, si no concurren las circunstancias que en cada caso se expresan"116 es "el sistema moderno, de la regularidad internacional de los fallos, consagrado en el artículo 245 del Código de Procedimiento Civil"117. Dicho sistema prevé que en aquellas ocasiones en que no pueda aplicarse ninguno de los dos modelos anteriores $^{118}$, el artículo 245 CPC. admite que las resoluciones de tribunales extranjeros tendrán en Chile "la misma fuerza que si se hubieran dictado por tribunales chilenos" siempre y cuando reúnan las condiciones fijadas en el precepto. Unas condiciones que dejan "de lado el control de la juridicidad material de lo que se trata de cumplir, materia entregada a la apreciación soberana del Estado de que forma parte de órgano jurisdiccional del que emanó la resolución"119, buscando probar la "subordinación del cumplimiento de la sentencia a ciertos requisitos superficiales, en el sentido de no entrar a analizar su justicia o injusticia intrínseca" ${ }^{120}$. En concreto el artículo 245 CPC. admite la eficacia en Chile de aquellas resoluciones extranjeras: " $1{ }^{a}$ Que no contengan nada contrario a las leyes de la República. Pero no se tomarán en consideración las leyes de procedimiento a que hay a debido sujetarse en Chile la substanciación del juicio; $2^{\mathrm{a}}$ Que tampoco se opongan a la jurisdicción nacional; $3^{\mathrm{a}}$ Que la parte en contra de la cual se invoca la sentencia hay a sido debidamente notificada de la acción. Con todo, podrá ella probar que, por otros motivos, estuvo impedida de hacer valer sus medios de defensa. $4^{\mathrm{a}}$ Que estén ejecutoriadas en conformidad a las leyes del pais en que hayan sido pronunciadas".

Este modelo, calificado de "liberal y tolerante" 121 , permite al Alto Tribu-

soluciones dictadas por tribunales chilenos en materia de asistencia penal son ejecutadas en los Estados Unidos de Norteamérica". Tal denegación se produce igualmente, y también respecto de una decisión de los Estados Unidos, en la sentencia de la Corte Suprema, de 25 de marzo de 2008, considerando $5^{\circ}$.

${ }^{115}$ En terminología de la propia Corte Suprema, véase: su sentencia de 8 de septiembre de 2011, considerando $3^{\circ}$.

${ }^{116}$ Corte Suprema, 11 de mayo de 2009, considerando $8^{\circ}$.

${ }^{117}$ Ibíd.

${ }^{118}$ Nótense al respecto, y entre otras, Corte Suprema, 2 de abril de 2003 considerando $2^{\circ} ; 2$ de abril de 2007, considerando $1^{\circ}$; de 10 de julio de 2008 .

${ }^{119}$ Corte Suprema, 14 de agosto de 2012, considerando $1^{\circ}$ DEG.

${ }^{120}$ Corte Suprema, 21 de marzo de 2001, considerando $5^{\circ}$.

${ }^{121}$ Monsalvez Müller, A., Cumplimiento en Chile de las sentencias dictadas por 
nal, y de acuerdo con la propia jurisprudencia de la Corte Suprema, examinar "a la luz de los antecedentes allegados a estos autos, el cumplimiento del mandato legal antes transcrito, teniendo presente, en todo caso, que este procedimiento de exequátur no es una instancia en la que corresponda debatir nuevamente el fondo del asunto resuelto en la sentencia cuya autorización de cumplimiento en Chile se solicita"122. Lo sustancial, en suma, es comprobar "que la sentencia tenga carácter de tal, que efectivamente hay a sido pronunciada por un tribunal del Estado requirente y que revisado por las instancias superiores no haya presentado reparos en sus formas, e incluso, presentándolos, hayan sido corregidos, de manera que permita su ejecución en ese país, si fuere del caso"123.

El tenor del precepto pone de manifiesto la ausencia de una presunción favorable al reconocimiento y ejecución de la resolución foránea, algo que, por el contrario, sí se encuentra por ejemplo en el artículo 36 de la "Ley de Arbitraje" 124 . De esta suerte, la eficacia de la decisión foránea sólo se producirá en Chile si se cumplen los requisitos previstos en el CPC. ${ }^{125}$. Esas sentencias tendrán en Chile la misma fuerza que si se hubieran dictado por tribunales chilenos, con tal que reúnan las circunstancias especificadas en el artículo 245 CPC. ${ }^{126}$.

Una primera lectura del artículo 245 CPC. y de las condiciones recogidas en el precepto, pone de manifiesto que éste no hace mención a requisitos previstos con carácter general en las legislaciones comparadas en relación con este punto. Así se obvia una mención expresa a la exigencia de autenticidad del documento extranjero o a su traducción. Igualmente, tampoco se menciona de forma directa la competencia del juez de origen ni la eventual contrariedad con el orden público. Estos tres requisitos sí aparecen recogidos en otros textos con vigencia en Chile en la materia: así ocurre en el derecho

tribunales internacionales, en Ius et Praxis, 2 (1997) 2, p. 215.

${ }^{122}$ Corte Suprema, 14 de mayo de 2007 considerando $11^{\circ}$ y 11 de mayo de 2009 , considerando $7^{\circ}$.

${ }^{123}$ Corte Suprema, 11 de mayo de 2009, considerando $12^{\circ}$.

${ }^{124}$ Artículo 36 inciso $1^{\circ}$ : "Sólo se podrá denegar el reconocimiento o la ejecución de un laudo arbitral, cualquiera que sea el país en que se haya dictado [...]". Esta misma posición se encuentra en el artículo V del "Convenio de Nueva York" de 1958 sobre ejecución de sentencias arbitrales extranjeras y en el artículo 5 de la Convención interamericana sobre arbitraje comercial internacional de 1975.

${ }^{125}$ También el antes mencionado artículo 423 CDIP. participa de esta ausencia de presunción favorable a la aceptación de la eficacia en el país de la decisión dictada fuera de las fronteras nacionales.

${ }^{126}$ Corte Suprema, 14 de agosto de 2012, considerando $2^{\circ}$ DEG. 
internacional privado ${ }^{127}$, en la "Ley de arbitraje" 128 o en los convenios sobre arbitraje que vinculan a Chile ${ }^{129}$.

Ciertamente podría decirse que la ausencia de mención a la autenticidad y a la traducción se puede salvar a través del régimen legal aplicable a los documentos públicos extranjeros ${ }^{130}$. Aunque ello refleje una clara falta de depuración técnica por parte del legislador. Mucho más complejo, empero, como seguidamente veremos, es el silencio que guarda el Código de Procedimiento Civil en relación con la verificación de la competencia del juez de origen o con la no contrariedad de la decisión extranjera con el orden público chileno. Las referencias a la no contrariedad con las leyes de la República, como observaremos al analizar seguidamente la práctica chilena en la materia, no sólo no resulta equivalente a la no contrariedad con los principios esenciales del modelo chileno -la no contrariedad con el orden público-, sino que sirve de base a la jurisprudencia chilena para interpretar el motivo de forma literal -contrariedad, en el sentido de no coincidencia, con la ley chilena-, y para contravenir uno de los principios esenciales sobre los que la propia Corte Suprema asienta el modelo de reconocimiento y ejecución de las resoluciones extranjeras: el de la no revisión del fondo de la decisión extranjera cuya eficacia se busca en Chile. Similares reflexiones pueden apuntarse en relación con la no verificación de la competencia del juez de origen. La jurisprudencia chilena interpreta la referencia a la no oposición a la jurisdicción nacional de una forma tan poco clara como carente de lógica desde un punto de vista internacionalprivatista.

La redacción del precepto ha dado lugar a una práctica jurisprudencial compleja, poco elaborada y en modo alguno a la altura de la realidad económica y social de un país a la vanguardia como es Chile. Una práctica reñida con los niveles mínimos de seguridad jurídica, justicia y previsibilidad que un país desarrollado debe asegurar a las decisiones de sus tribunales. Y en la que desde un punto de vista argumentativo se combinan situaciones en las que se produce una referencia lineal al artículo 245 CPC. sin entrar a valorar de forma individualizada ninguno de sus motivos ${ }^{131}$, con otras en las que, como seguidamente veremos, se alcanzan soluciones en modo alguno coincidentes con las mantenidas de forma generalizada y habitual en el plano comparado.

${ }^{127}$ Artículo 423 CDIP.

${ }^{128}$ Artículo 36 LA.

${ }^{129}$ Artículo 5 de la Convención sobre arbitraje comercial internacional de 1975 o V del Convenio sobre ejecución de sentencias arbitrales extranjeras de 1958.

${ }^{130}$ Recordemos, los artículos 420 inciso $5^{\circ}$ COT., 345 y 347 CPC. y 17 y 1699 a 1701 CC.

${ }^{131}$ Corte Suprema, 26 de septiembre de 2005; 21 de enero de 2008, considerando $15^{\circ}$ o de 26 de marzo de 2009. 
a) Primer motivo: "Que no contengan nada contrario a las leyes de la República. Pero no se tomarán en consideración las leyes de procedimiento a que haya debido sujetarse en Chile la sustanciación del juicio".

De acuerdo con el primer apartado del artículo 244 CPC. la decisión foránea producirá efectos en Chile en tanto en cuanto no incorpore en su mandato nada que sea contrario a las leyes sustantivas chilenas. Tal como señala el precepto, se obvian las leyes de procedimiento a que haya debido sujetarse en Chile la sustanciación del juicio. La práctica jurisprudencial chilena refleja un aumento constante en el número de motivos utilizados por las partes que se oponen a la eficacia de la decisión foránea en la República ${ }^{132}$, y algunos de estos motivos afectan directamente a esta última regla. Entre ellos, por ejemplo, se encuentra la alegación de imposibilidad de defensa. La Corte Suprema ha considerado que la alegación de existencia de un breve plazo para contestar a la demanda constituye una cuestión procesal que debe ser rechazada al amparo del mandato del artículo 245 inciso $1^{\circ}$ CPC..$^{133}$.

Una primera lectura de este motivo de concesión del exequátur conduciría a pensar que incorpora una referencia un tanto abstrusa al principio de la no contrariedad con el orden público, presumiblemente, internacional ${ }^{134}$. El único principio, de general aceptación en el plano comparado, a través del cual se puede cotejar el contenido de la resolución foránea cuya eficacia se solicita en el país. Un principio, además, que aparece recogido explícitamente, como ya hemos dicho, tanto en el Código de Derecho Internacional Privado y en el "Acuerdo de cooperación del MERCosur", como en la "Ley de Arbitraje”, en la nueva Ley de matrimonio civil o en los convenios sobre reconocimiento de laudos arbitrales que vinculan a Chile. La contrariedad con el orden público supone, sin embargo, un cotejo de los efectos producidos por la decisión extranjera, no técnicamente de su contenido, en relación con los principios esenciales del sistema en cuyo seno se pretende lograr la eficacia de la decisión extranjera. Principios esenciales aplicables a las situaciones que presentan elementos de extranjería -orden público internacional-, no disposiciones legales positivizadas. De esta suerte, aquellas decisiones foráneas de las que se deriven unos efectos que contradicen los principios esenciales del ordenamiento jurídico del país al que se solicita el exequatur deberán ser rechazadas. De qué principios en concreto se trate es algo a

${ }^{132}$ Véase el cap. IV, 5.

${ }^{133}$ Véase la sentencia de la Corte Suprema de 24 de enero de 2005, considerando $4^{\circ}$.

${ }^{134}$ A favor de esta posición, véase: Guzmán Latorre, D., cit. (n. 27), p. 583. El autor entiende que junto a esta mención, la regla del artículo 245 inciso $1^{\circ} \mathrm{CPC}$. incorpora una referencia al hecho de que la sentencia extranjera no se haya dictado con base en una ley distinta a la chilena, cuando de acuerdo con las normas de derecho internacional privado debería haberse dictado de acuerdo a ésta (p. 583). 
determinar por el tribunal que conoce de la solicitud de reconocimiento y ejecución caso por caso.

La Corte Suprema ha apoyado en alguna ocasión aislada esta interpretación, considerando que el tenor del artículo 245 inciso $1^{\circ} \mathrm{CPC}$. implica y debe interpretarse como una mención a la eventual contrariedad con el orden público internacional chileno: "esto es, que no contenga nada contrario al orden público nacional. La sentencia cuyo cumplimiento se pretende condena a los demandados al pago de una indemnización de perjuicios derivados de apropiación indebida de fondos, incumplimiento de contrato y fraude, lo que se encuadra dentro del ámbito del derecho privado, sin que resulten vulneradas normas de orden público, fundamento suficiente para desestimar la alegación del demandado"135. A pesar de combinar una mención al orden público principios esenciales del sistema- con las normas de orden público -normas de derecho positivo de necesaria aplicación- la Corte Suprema parece tener claro lo que el artículo 245 inciso $1^{\circ} \mathrm{CPC}$. supone y significa.

Sin embargo, se trata de una posición aislada. La lectura literal del tenor del motivo refleja que éste no refiere al orden público, sino que claramente habla de que la decisión extranjera no contenga nada que sea contrario a las leyes sustantivas de la República. Algo mucho más amplio que la no contrariedad con los principios esenciales de nuestro sistema y que contradice, como seguidamente observaremos, algunos de los principios esenciales sobre los que la Corte Suprema ha manifestado que se asienta la figura del exequatur. Este tenor del artículo 244 inciso $1^{\circ} \mathrm{CPC}$. ha llevado a la propia Corte Suprema a considera que en el precepto se está haciendo mención a algo distinto al orden público, patentizando este carácter diferencial, en su práctica jurisprudencial.

La cuestión, como señala la propia doctrina chilena, es conocer que quiere exactamente decir el legislador chileno con esta norma: "¿Quiere ello decir que la resolución debía dictarse en conformidad a las leyes chilenas? Evidentemente que no. La sentencia se pronuncia de acuerdo a la ley competente $y$, en esa forma resulta muy difícil que un fallo extranjero no contenga nada contrario a las leyes chilenas. De ahí que es recomendable interpretar esta disposición con amplitud de criterio, puesto que una interpretación muy literal nos llevaría al absurdo de no dar cumplimiento a ninguna sentencia extranjera"136. La Corte Suprema parece desatender en su práctica, punto por punto, lo que acabamos de referir.

De esta suerte, y como regla general, la Corte Suprema, lejos de analizar los valores o principios sobre los que se asienta el modelo jurídico chileno,

${ }^{135}$ Corte Suprema, 25 de marzo de 2008, considerando $7^{\circ}$.

${ }^{136}$ GuZMán Latorre, D., cit. (n. 27), p. 583. 
procede a valorar otros extremos relacionados con la sustancia de la decisión extranjera. Así, tiende a analizar si la acción ejercitada ante el tribunal extranjero y que dio lugar en su día a la sentencia cuyo exequatur se solicita, "está prevista en el ordenamiento patrio, según la normativa en vigor" 137 . O, si el objeto de la acción que sirve de base a la sentencia foránea "guarda armonia con la legislación nacional sobre la materia" 138 y por ello "no contraviene las leyes de la República"139. Y ello, insistimos, aun aceptando con claridad que el procedimiento de exequátur implica una mera revisión formal de la decisión extranjera: "este procedimiento de exequátur no es una instancia en la que corresponda debatir nuevamente el fondo del asunto resuelto en la sentencia cuya autorización de cumplimiento en Chile se solicita"140, y por lo tanto "se limita puntualmente al cumplimiento por parte de la sentencia extranjera de las exigencias del artículo 245 del Código de Procedimiento Civil, y no a una revisión jurídica del juicio mismo, de modo tal que no se puede entrar a determinar si el actor acreditó o no la existencia de la obligación cuyo cumplimiento reclamó del Sr. XXX, quien pudo comparecer a dicho pleito y hacer todas las defensas que la ley extranjera le permite y, si no lo hizo, no puede, en el exequátur, plantear defensas o alegaciones que debió hacer en aquella sede"141.

Este punto de partida lleva a la Corte Suprema a una jurisprudencia muy expansiva en relación con el motivo contenido en el artículo 24 inciso $1^{\circ} \mathrm{CPC}$. Y así, lejos de desatender su exigencia de limitar la verificación de la decisión extranjera al ámbito meramente formal de ésta, sin entrar en el fondo de la decisión extranjera salvo para rechazarla en aquellos supuestos de contrariedad con los principios esenciales del Derecho sustantivo del foro -entendiendo en tal sentido, como su propia jurisprudencia señala, que las condiciones previstas en el artículo 245 CPC. constituyen un conjunto de "requisitos superficiales"142 que para nada permiten entrar en el fondo del litigio-, la Corte Suprema no duda en entrar a valorar de lleno el contenido de la decisión extranjera.

Este estándar rígido de adecuación plena a la ley chilena en cuanto no se coteja, como dice el precepto, si el fondo de la sentencia contradice o no la ley

${ }^{137}$ Corte Suprema, 2 de abril de 2007, considerando $4^{\circ}$.

${ }^{138}$ Corte Suprema de 10 de mayo de 2010, considerando $5^{\circ}$.

${ }^{139}$ Corte Suprema, 9 de noviembre de 2011, considerando $6^{\circ}$. La solución resulta especialmente llamativa dado que en este supuesto se procedió a aplicar el artículo 423 CDIP. lo que, atendido al tenor del artículo 242 CPC. no permite la aplicación del artículo 245 CPC. en el que se recoge esta exigencia de no contravenir las leyes de la República. Similar solución se alcanza en la Corte Suprema de 18 de abril de 2011, considerando $4^{\circ}$.

${ }^{140}$ Corte Suprema, 25 de marzo de 2008, considerando $6^{\circ}$.

${ }^{141}$ Corte Suprema, 24 de enero de 2005, considerando $6^{\circ}$.

${ }^{142}$ Corte Suprema, 21 de marzo de 2001, considerando $5^{\circ}$. 
sustantiva chilena, sino que se va más allá buscando la identidad con ésta, es utilizado de forma generalizada para otorgar o denegar el exequátur solicitado al creciente número de decisiones extranjeras cuya eficacia se pretende en Chile: sentencias, por ejemplo, sobre alimentos ${ }^{143}$, sobre incumplimiento de contratos $^{144}$, respecto de condenas de cantidad ${ }^{145}$ o en relación con acciones civiles de cobro de dinero por incumplimiento contractual ${ }^{146}$.

Esta línea argumental permite a la Corte Suprema superar con creces la mera revisión formal y proceder a valorar en sentido estricto el contenido de la decisión foránea, para comprobar hasta qué punto ésta contiene o no algo contrario a las leyes de la República. De esta suerte, no ha dudado en señalar que la decisión dictada por un Tribunal de Estados Unidos de Norteamérica y que concede la custodia del hijo al padre, contraría el mandato del artículo 225 CCC., sin que se demuestre la existencia de alguna de las excepciones prevista en el artículo 226 del mismo cuerpo legal ${ }^{147}$. Añadiendo, además, que: "el referido fallo no se funda ni da cuenta de circunstancias respecto de la particular situación de los menores, ni de los beneficios que podria reportarle la decisión adoptada, por lo que no queda en evidencia el interés superior del niño, principio fundamental al que el juez debe atender como consideración fundamental, conforme lo prescribe el ordenamiento nacional" ${ }^{148}$. Igualmente, se afirma que la decisión extranjera no toma en consideración un previo fallo de un tribunal chileno en el que se rechazó la demanda presentada por el padre en contra la madre, sin señalar sobre qué versaba dicho fallo o cuando se dictó $^{149}$. Ni tampoco ha tenido problema alguno en limitar, en otra ocasión, la potencial concesión del exequátur tan solo en relación con aquellas obligaciones que no superen una concreta cantidad, dado que los artículos 517 y 550 CC., que regulan la naturaleza y efectos del contrato de seguro y establecen requisitos y prohibiciones, limitan la suma a pagar en concepto de indemnización ${ }^{150}$.

La Corte Suprema no hace mención a la contrariedad con el orden público o a la violación de normas imperativas chilenas. Se limita a valorar si una decisión como la extranjera cuya eficacia se busca en Chile hubiera podido ser dictada por los tribunales chilenos, y hubiera obtenido con base en la legislación chilena una solución idéntica a la alcanzada por el tribunal

\footnotetext{
${ }^{143}$ Corte Suprema, 2 de abril de 2007.

${ }^{144}$ Corte Suprema, 21 de marzo de 2001, considerando $8^{\circ}$.

${ }^{145}$ Corte Suprema, 7 de noviembre de 2013, considerando $4^{\circ}$.

${ }^{146}$ Corte Suprema, 11 de mayo de 2009, considerando $12^{\circ}$.

${ }^{147}$ Corte Suprema, 17 de junio de 2013, considerando $5^{\circ}$.

${ }^{148}$ Ibíd., considerando $6^{\circ}$.

${ }^{149}$ Ibíd., considerando $7^{\circ}$.

${ }^{150}$ Corte Suprema, 21 de enero de 2008, considerando $11^{\circ}$.
} 
foráneo. No hay flexibilidad alguna, y no ha lugar al juego de figuras clásicas del derecho internacional privado como la equivalencia de instituciones. Como consecuencia de ello, el resultado alcanzado además de rígido no resulta equiparable a los estándares mantenidos en el plano comparado en relación con este punto.

Esta línea argumental maximalista demuestra sus efectos más negativos en tres ámbitos muy concretos de naturaleza muy diferente: en relación con las decisiones que afectan a bienes inmuebles radicados en el país, en materia de sucesiones y en materia de disolución del vínculo matrimonial.

i) Decisiones extranjeras que afectan a bienes radicados en Chile. El artículo 16 CC. precisa que los "bienes situados en Chile están sujetos a las leyes chilenas, aunque sus dueños sean extranjeros y no residan en Chile". Esta disposición, añade el apartado 2 del precepto, debe entenderse "sin perjuicio de las estipulaciones contenidas en los contratos otorgados válidamente en país extraño". Aunque en todo caso, y tal como precisa el último párrafo del artículo, "los efectos de los contratos otorgados en país extraño para cumplirse en Chile, se arreglarán a las leyes chilenas" 151 . Este mandato taxativo daría lugar a que cualquier decisión extrajera que vinculase bienes radicados en Chile a una legislación extranjera se entendiese como contraviniendo el mandato del artículo 245.1 CPC. Y ello, aunque es muy escasa la jurisprudencia que analiza directamente la proyección de este precepto en el ámbito del reconocimiento y ejecución de resoluciones extranjeras en Chile ${ }^{152}$.

ii) Decisiones extranjeras sobre sucesiones en las que existen bienes en Chile. La radicalidad con que se aproxima el tenor del artículo $16 \mathrm{CC}$. encuentra una manifestación muy clara en relación con el reconocimiento de decisiones extranjeras en materia sucesoria que afectan a bienes localizados en Chile. Y ello de forma doblemente negativa:

En primer lugar, por cuanto el mandato del artículo 16 CC., especialmente de su primer párrafo, se pone en relación con el tenor del artículo 27 de la Ley $\mathrm{N}^{\circ} 16.271$ sobre Impuesto a las herencias, asignacionesy donaciones, que dispone: "Cuando la sucesión se abra en el extranjero -cuyo es el caso de autos-deberá pedirse en Chile, no obstante lo dispuesto en el artículo 955 del Código Civil, la posesión efectiva de la herencia respecto de los bienes situados dentro del territorio chileno, para los efectos del pago de los impuestos establecidos por esta ley. La posesión efectiva, en este caso, deberá pedirse en el lugar

${ }^{151}$ En relación con el origen histórico de este precepto y su aplicabilidad, nótese: Grob Duhald, F. J., La ley aplicable a los contratos internacionales en ausencia de elección por laspartes, en Revista Chilena de Derecho,41 (2014), pp. 237 ss.

${ }^{152}$ Así se precisa en el considerando $13^{\circ}$ de la sentencia de la Corte Suprema de 14 de mayo de 2007. En este caso, sin embargo, se entendió que se estaban valorando garantías personales y no reales, de ahí que el artículo $16 \mathrm{CC}$. no se considerase violado. 
en que tuvo el causante su último domicilio en Chile, o en el domicilio del que pida la posesión efectiva, si aquél no lo hubiera tenido". Y con el mandato del artículo 149 COT. que asume esta exigencia al afirmar: "Cuando una sucesión se abra en el extranjero y comprenda bienes situados dentro del territorio chileno, la posesión efectiva de la herencia deberá pedirse en el lugar en que tuvo el causante su último domicilio en Chile, o en el domicilio del que la pida si aquél no lo hubiera tenido".

Ello conduce a la Corte Suprema a atribuir competencia exclusiva a la jurisdicción chilena para decidir sobre el otorgamiento de la posesión efectiva de una sucesión que comprenda bienes radicados en Chile: "Que la normativa precedente, como se aprecia, deja entregado exclusivamente a la jurisdicción de los tribunales chilenos el decidir sobre el otorgamiento de la posesión efectiva de una sucesión que comprenda bienes situados en Chile [... $]^{153}$. Esta competencia exclusiva no se extiende a la partición y adjudicación de los inmuebles situados en Chile realizada por un tribunal extranjero que, al coincidir con lo previsto en el artículo 1325 CC., se entiende que "se ajusta a lo dispuesto en dich a norma respecto de la partición de bienes, por lo que no contraviene la legislación nacional" ${ }^{154}$. Limitándose a recordar a los interesados que, una vez obtenido el exequátur de la decisión extranjera "es necesario que en su oportunidad se solicite ante el tribunal chileno que corresponda la posesión efectiva de la herencia quedada al fallecimiento" del causante"155.

En segundo lugar, por cuanto la propia Corte Suprema no deja claro si estamos ante un supuesto valorable al amparo de los apartados $1^{\circ}$ ó $2^{\circ}$ del artículo 245 CPC. Así, si bien existen resoluciones en que la opción parece inclinarse a favor del apartado $1^{\circ 156}$, hay otras similares -sentencias que reconocen la condición de herederos y atribuyen bienes de la herencia- en las que la valoración se produce, directamente, en relación con el apartado 2 del mencionado precepto ${ }^{157}$, aunque en ocasiones se haga también mención conjunta a ambos requisitos ${ }^{158}$. Tal valoración, además, se realiza usando idénticos términos en un caso o en otro ${ }^{159}$, como si se tratase de motivos intercambiables, o los criterios justificativos aplicables al conflicto de leyes

\footnotetext{
${ }^{153}$ Corte Suprema, 2 de julio de 2014, considerando $6^{\circ}$.

${ }^{154}$ Ibíd., considerando $7^{\circ}$.

${ }^{155}$ Ibíd., considerando $6^{\circ}$.

${ }^{156}$ Ibíd., considerando $7^{\circ}$.

${ }^{157}$ Corte Suprema, 3 de noviembre de 2003, considerando $4^{\circ} ; 2$ de diciembre de
} 2003 , considerando $4^{\circ}$; de 23 diciembre de 2003, considerando $3^{\circ} ; 11$ de junio de 2008 , considerando $3^{\circ}$.

${ }^{158}$ Corte Suprema de 8 de junio de 2009, considerando $3^{\circ}$.

${ }^{159}$ Corte Suprema, 3 de noviembre de 2003, considerando $5^{\circ} ; 2$ de diciembre de 2003, considerando $5^{\circ} ; 23$ de diciembre de 2003 , considerando $4^{\circ} ; 11$ de junio de 2008 , considerando $4^{\circ} ; 8$ de junio de 2009 , considerando $4^{\circ}$. 
resultaran coincidentes con los utilizables para verificar la oposición a la jurisdicción nacional. Y lo más llamativo; alcanzándose respuestas diferentes en relación con la concesión o denegación del exequátur solicitado ${ }^{160}$.

iii) Decisiones extranjeras sobre divorcio. La eficacia en Chile de decisiones extranjeras de nulidad, separación y, fundamentalmente, divorcio constituye el ámbito sectorial donde con mayor intensidad y amplitud se ha valorado el mandato del artículo 245.1 CPC.

En relación con la nulidad, tradicionalmente la Corte Suprema procedió de forma mayoritaria a conceder el exequátur de las decisiones extranjeras cuya eficacia se solicitaba en Chile. ${ }^{161}$ Algo contrario a lo ocurrido respecto de las decisiones extranjeras de separación matrimonial en las que, como ya se ha apuntado anteriormente, la Corte Suprema no duda en denegar el exequatur a una decisión foránea de separación -sentencia que no implica la ruptura del vínculo matrimonial, recordemos-amparándose en el mandato de la Ley $\mathrm{N}^{\circ} 19.947$-que admite el divorcio-y en sus normas transitorias ${ }^{162}$.

Centrándonos en la práctica existente en relación con la eficacia en Chile de las decisiones extranjeras de divorcio, lógicamente debe distinguirse como punto de inflexión la fecha de 2004, año en que se aprueba la nueva Ley de matrimonio civil. Hasta esa fecha, las decisiones extranjeras en materia de divorcio veían denegadas, de forma mayoritaria, el exequátur con argumentaciones diversas y base en la ausencia de la institución del divorcio en el ordenamiento jurídico patrio ${ }^{163}$. Y decimos mayoritaria por cuanto existe alguna decisión de la Corte Suprema que llamativamente procedió a otorgar el exequatur solicitado a decisiones extranjeras de divorcio, a pesar de no reconocerse el divorcio en Chile "porque la sentencia no contiene nada contrario a las leyes de la República ni se opone a la jurisdicción nacional, ambaspartes han comparecido solicitando su cumplimiento y la sentencia está ejecutoriada"164.

La promulgación de la Ley $\mathrm{N}^{\circ}$ 19.947, el 17 de mayo de 2004, supuso una inflexión en la situación mantenida hasta el momento, al introducirse la figura de la disolución del vínculo matrimonial por divorcio en el orde-

${ }^{160}$ Corte Suprema, 3 de noviembre de 2003, considerando $6^{\circ} ; 2$ de diciembre de 2003, considerando $5^{\circ} ; 23$ de diciembre de 2003, considerando $5^{\circ}$, en las que se denegó el exequátur. Corte Suprema, 11 de junio de 2008, considerando $5^{\circ} ; 8$ de junio de 2009, considerando $5^{\circ}$, en que se concedió.

${ }^{161}$ Corte Suprema, 10 de octubre de 2000, que concede el exequátur, con un voto disidente sin entrar a cotejar la sentencia extranjera con las causas previstas en el artículo 245 CPC.; 27 de septiembre de 2006 o de 24 de marzo de 2009, también favorables.

${ }^{162}$ Corte Suprema, 28 de junio de 2006, considerandos $6^{\circ}, 8^{\circ}$ y $9^{\circ}$.

${ }^{163}$ Así, a modo de ejemplo véase: entre otras muchas, Corte Suprema 1 de diciembre de 1999; 2 de diciembre de 1999 o 5 de julio de 2000 que proceden a denegar el exequátur solicitado.

${ }^{164}$ Corte Suprema, 28 de marzo de 2000 , considerando $2^{\circ}$, con un voto disidente. 
namiento jurídico chileno. Este cambio, lógicamente, ha tenido un reflejo en la práctica jurisprudencial en la materia. Una práctica que, sin embargo, y como ya se ha avanzado, no ha supuesto la revolución que hubiera sido lógica atendida la magnitud del cambio legislativo producido, y que se ha visto rígidamente atemperada por la decisión de atender estrictamente al mandato de la ley y a sus normas transitorias, a la hora de valorar la concesión o no del exequatur solicitado.

Así, respecto de aquellas sentencias de divorcio dictadas fuera de Chile, tanto con posterioridad como con anterioridad ${ }^{165}$ a la entrada en vigor de la ley, la Corte Suprema valora con absoluta rigidez el cumplimiento de la mencionada ley ${ }^{166}$. Y en tal sentido, la Corte Suprema, independientemente de que sea aplicable al supuesto, o no, el "Código Bustamante"167, analiza si se satisfacen los requisitos recogidos en el artículo 83 de la nueva Ley de matrimonio civil. Un precepto que significativa remite el procedimiento de exequatur a lo dispuesto en el Código de Procedimiento Civil y que, sin embargo, recoge dos conceptos que no aparecen presentes en el Código de Procedimiento Civil: la noción de "orden público chileno" y la idea del control de la competencia del juez de origen: "Artículo 83. El divorcio estará sujeto a la ley aplicable a la relación matrimonial al momento de interponerse la acción./ Las sentencias de divorcio y nulidad de matrimonio dictadas por tribunales extranjeros serán reconocidas en Chile conforme a las reglas generales que establece el Código de Procedimiento Civil./ En ningún caso tendrá valor en Chile el divorcio que no haya sido declarado por resolución judicial o que de otra manera se oponga al orden público chileno./ Tampoco se reconocerá valor a las sentencias obtenidas en fraude a la ley. Se entenderá que se ha actuado en fraude a la ley cuando el divorcio ha sido declarado bajo una jurisdicción distinta a la chilena, a pesar de que los cónyuges hubieren tenido domicilio en Chile durante cualquiera de los tres años anteriores a la sentencia que sepretende

${ }^{165}$ Atendido el inciso final del artículo $2^{\circ}$ transitorio, introducido por la Ley $\mathrm{N}^{\circ}$ 20.286 de 15 de septiembre de 2008, que señala: "De conformidad al inciso primero, habiéndose previamente cumplido el procedimiento sobre ejecución de las resoluciones pronunciadas por tribunales extranjeros, regulados por los articulos 242 y siguientes del Código de Procedimiento Civil, las sentencias relativas a divorcios pronunciados por tribunales extranjeros tendrán fuerza en Chile, sin perjuicio de haber sido dictadas con anterioridad a la fecha de entrada en vigencia de esta ley". Véanse al respecto y entre otras muchas, Corte Suprema, 27 de marzo de 2008, considerandos $8^{\circ}$ y $9^{\circ}$; o 26 de febrero de 2009 , considerando $4^{\circ}$.

${ }^{166}$ Significativas al respecto son las sentencias de la Corte Suprema de 28 de julio de 2008 , considerando $2^{\circ}$, especialmente considerando $10^{\circ}$, o de 21 de agosto de 2008 , considerandos $5^{\circ}$ a $9^{\circ}$, entre otras.

${ }^{167}$ A modo de ejemplo, la sentencia de la Corte Suprema de 21 de junio de 2010, considerando $2^{\circ}$. Considérese, igualmente, la nota 174 . 
ejecutar, si ambos cónyuges aceptan que su convivencia ha cesado a lo menos ese lapso, o durante cualquiera de los cinco años anteriores a la sentencia, si discrepan acerca del plazo de cese de la convivencia. El acuerdo o la discrepancia entre los cónyuges podrá constar en la propia sentencia o ser alegado durante la tramitación del exequátur".

$\mathrm{Al}$ amparo de este precepto serán reconocidas en Chile aquellas sentencias extranjeras de divorcio que: i) Hayan sido declaradas por resolución judicial. La Corte Suprema en su Sentencia de 26.4.2006 aborda precisamente esta cuestión. La sentencia cuyo exequátur se solicitaba fue dictada por una autoridad administrativa danesa, y no por un juez mediante una sentencia, lo que motivó su denegación ${ }^{168}$; ii) Que no sean contrarias al orden público chileno $^{169}$; y iii) Que no hayan sido obtenidas en fraude de ley, esto es, que el divorcio no haya sido declarado bajo una jurisdicción distinta a la chilena, a pesar de que los cónyuges hubieren tenido domicilio en Chile durante cualquiera de los tres años anteriores a la sentencia que se pretende ejecutar, si hay acuerdo al respecto. $\mathrm{O}$ durante cualquiera de los cinco años anteriores a la sentencia, si discrepan acerca del plazo de cese de la convivencia ${ }^{170}$.

Este artículo 83, además, se pone en relación con los artículos 42 inciso $4^{\circ}$ y 55 de la propia ley, de los que se deriva que ${ }^{171}: i v$ ) El divorcio ha de ser otorgado necesariamente por un juez, -no cabe que sea otorgado por notarios, encargados del Registro Civil o similares ${ }^{172}$; y $v$ ) Que no basta el mutuo acuerdo de los cónyuges, siendo necesario el cese de la convivencia por un plazo no menor a un año ${ }^{173}$.

El análisis de estos cinco requisitos basa toda la práctica chilena en relación con la concesión, o no, del exequátur a las decisiones extranjeras de divorcio. Una práctica articulada a partir de una posición mayoritariamente favorable

${ }^{168}$ Corte Suprema, 26 de abril de 2006, considerandos $4^{\circ}$ y $5^{\circ}$.

${ }^{169}$ Véase la sentencia de la Corte Suprema de 23 de octubre de 2008, considerando $4^{\circ}$

${ }^{170}$ Véanse, entre otras muchas, la sentencias de la Corte Suprema de 18 de agosto de 2008 , considerando $9^{\circ}$; de 29 de septiembre de 2008 , considerandos $6^{\circ}$ y $9^{\circ}$; de 23 de octubre de 2008 , considerando $4^{\circ}$; de 26 de febrero de 2009 , considerandos. $7^{\circ} \mathrm{y}$ $10^{\circ}$; de 1 de abril de 2009 , considerando $10^{\circ}$. O la sentencia de la Corte Suprema de 27 de septiembre de 2006 , considerando $8^{\circ}$, en relación con una sentencia extranjera de nulidad.

${ }^{171}$ Véase la sentencia de la Corte Suprema de 1 de abril de 2009, considerando $7^{\circ}$.

${ }^{172}$ Véase la sentencia de la Corte Suprema de 23 de octubre de 2008, considerando $4^{\circ}$.

${ }^{173}$ Véanse las sentencias de la Corte Suprema de 18 de agosto de 2008, considerandos $4^{\circ}$ y $6^{\circ}$; de 26 de febrero de 2009 , considerando $7^{\circ}$; de 6 de agosto de 2012 , considerando $5^{\circ}$. Igualmente, la sentencia de la Corte Suprema de 29 de noviembre de 2010, que aplica el "Código Bustamante", y que deniega el exequátur solicitado con base en la ausencia de acreditación de este extremo (considerandos $4^{\circ}$ y $5^{\circ}$ ). 
a la concesión del exequátur solicitado ${ }^{174}$, y en la que la linealidad en las respuestas alcanzadas trasluce una aparente inclinación de la Corte Suprema de Justicia al corta-pega a la hora de proceder a razonar y fundamentar las decisiones dictadas en esta materia. Hasta el punto de que alguna sentencia no duda en constatar el incumplimiento sistemático de las condiciones previstas en el Código de Procedimiento Civil y en la nueva Ley de matrimonio civil para conceder el exequátur, afirmando que todo ello conduce a considerar en relación con la sentencia extranjera cuyo exequátur se solicita que "no es dable autorizar su ejecución en estepais" ${ }^{175}$, para, sin embargo, acabar concediendo de forma llamativa el exequátur solicitado ${ }^{176}$.

Esta linealidad en las respuestas alcanzadas se combina, empero, con ciertas soluciones e interpretaciones que, cuanto menos, resultan llamativas, creándose por parte de la Corte Suprema de Justicia una serie de requisitos adicionales para la eficacia en Chile de las sentencias extranjeras de divorcio que carecen de un claro respaldo normativo:

i) Así, por ejemplo, la mención que realiza el apartado $1^{\circ}$ del artículo 83 de la nueva Ley de matrimonio civil, que refiere la regulación del divorcio a la ley aplicable a la relación matrimonial en el momento de interponerse la acción, ha sido errónea y reiteradamente interpretada como refiriendo a la competencia del juez de origen. Justo la causa prevista en el artículo 245.2 CPC. y que, como seguidamente veremos, la Corte Suprema no acaba de comprender: "Que el inciso primero del artículo 83 de la Ley $N^{\circ} 19.947$ prescribe que 'el divorcio estará sujeto a la ley aplicable a la relación matrimonial al mo-

${ }^{174}$ Así, las sentencias de la Corte Suprema, de 15 de febrero de 2010; de 31 de mayo de 2010; de 21 de junio de 2010; de 23 de junio de 2010; de 10 de enero de 2011; de 17 de enero de 2011; de 24 de enero de 2011(2); de 21 de marzo de 2011; de 16 de mayo de 2011; de 29 de septiembre de 2011; de 24 de octubre de 2011; de 27 de febrero de 2012; de 19 de marzo de 2012; de 25 de junio de 2012; de 6 de agosto de 2102; de 24 de septiembre de 2012; de 25 de febrero de 2013; de 8 de agosto de 2013; de 13 de enero de 2014; de 7 de abril de 2014; de 14 de abril de 2014; de 21 de abril de 2014; de 6 de mayo de 2014; de 16 de junio de 2014; de 7 de julio de 2014. Y de 5 de enero de 2010; de 18 de octubre de 2010; de 17 de enero de 2011; de 28 de octubre de 2011; de 9 de noviembre de 2011; de 24 de diciembre de 2012; de 1 de julio de 2013; de 15 de abril de 2013; de 16 de septiembre de 2013 que combinan la aplicación del "Código Bustamante" con la nueva Ley de matrimonio civil,

${ }^{175}$ Corte Suprema, 12 de marzo de 2012, considerando $6^{\circ}$.

${ }^{176}$ Corte Suprema, 12 de marzo de 2012 in fine: " $Y$ de conformidad, con lo antes expuesto y disposiciones citadas, se acoge el exequátur solicitado en lo principal de fojas 12, para que se lleve a efecto en Chile la sentencia de divorcio del matrimonio celebrado [...], pronunciada el 21 de julio de 2010, dictada por el Juzgado de Primera Instancia 14 de Barcelona, España". 
mento de interponerse la acción', en este caso, a la jurisdicción de los tribunales de Brasil, lo que en la especie se cumple plenamente"177.

ii) Junto con ello, se exige la coincidencia entre las causales que motivaron la concesión del divorcio en el extranjero y las previstas en la Ley de matrimonio civil; un motivo en última instancia en línea con el mandato del artículo 245 inciso $1^{\circ} \mathrm{CPC} .{ }^{178}$. La ausencia de motivos que sean asimilables a alguna causal de divorcio del ordenamiento nacional contravendría, así, "las leyes de la República, en la medida que significa la disolución de un matrimonio por un motivo que no puede ser homologado a alguna causal prevista por el ordenamiento patrio, según la normativa actualmente vigente"179.

iii) Esta última idea de homologación es aceptada de forma nítida por la jurisprudencia chilena, aplicándose de hecho en alguna ocasión en que la causal con base en la que se concedió el divorcio en el extranjero no era idéntica a las recogidas en la legislación chilena pero se entendió subsumible en alguna de ellas ${ }^{180}$. Mas, correlativamente, y al amparo de la idea de que "las disposiciones que regulan el estado civil de laspersonas son normas de orden público", se precisa que "por lo tanto, las sentencias extranjeras que dispongan el divorcio deben decretarlo por causales que puedan homologarse con aquellas que la legislación nacional acepta para justificarlo"181. Consecuentemente,

${ }^{177}$ Corte Suprema, 1 de abril de 2009, considerando $6^{\circ}$. En idéntico sentido, las sentencias de la Corte Suprema de 18 de agosto de 2008, considerando $5^{\circ}$, de 26 de febrero de 2009 , considerando $6^{\circ}$; de 29 de septiembre de 2009 , considerando $5^{\circ}$; de 13 de septiembre de 2010 , considerando $5^{\circ}$; de 15 de noviembre de 2010 , considerando $4^{\circ}$; de 27 de diciembre de 2010 , considerando $6^{\circ}$; de 17 de enero de 2011 , considerando $4^{\circ}$; de 2 de julio de 2011 , considerando $5^{\circ}$; de 12 de septiembre de 2011 , considerando $4^{\circ}$; de 3 de noviembre de 2011 , considerando $5^{\circ}$; de 12 de noviembre de 2012 , considerando $5^{\circ}$; de 26 de febrero de 2014, considerando $4^{\circ}$; de 12 de junio de 2014, considerando $5^{\circ}$.

${ }^{178}$ Véanse Corte Suprema, 6 de mayo de 2010, considerando $7^{\circ}$ (que aplica el "Código Bustamante" y la Ley de matrimonio civil); de 4 de abril de 2011, considerando $6^{\circ}$.

${ }^{179}$ Sentencias de la Corte Suprema de 18 de marzo de 2000 , considerando $7^{\circ}$; de 3 de enero de 2011 (considerando $6^{\circ}$; de 5 de septiembre de 2011 , considerando $5^{\circ}$; de 18 de noviembre de 2011 , considerando $5^{\circ}$; de 7 de mayo de 2012 , considerando $5^{\circ}$; de 11 de junio de 2012 , considerando $5^{\circ}$; de 8 de octubre de 2012, considerando $5^{\circ}$; de 9 de septiembre de 2013, considerando $6^{\circ}$.

${ }^{180}$ Corte Suprema, 19 de abril de 2010, considerando $8^{\circ} ; 27$ de diciembre de 2010, considerando $5^{\circ} ; 26$ de enero de 2011 , considerando $8^{\circ} ; 12$ de noviembre de 2012 , considerando $7^{\circ} ; 14$ de abril de 2013 , considerando $8^{\circ}$ o 24 de junio de 2014 , considerando $8^{\circ}$.

${ }^{181}$ La sentencia de la Corte Suprema de 29 de noviembre de 2010, considerando $6^{\circ}$. En idéntico sentido Corte Suprema, 12 de julio de 2011, considerando $8^{\circ} ; 28$ de noviembre de 2011 , considerando $6^{\circ} ; 11$ de junio de 2011 , considerando $6^{\circ} ; 31$ de diciembre de 2012 , considerando $6^{\circ} ; 29$ de abril de 2013 , considerandos $6^{\circ}$ y $9^{\circ} ; 25$ de marzo de 2013, considerando $7^{\circ} ; 5$ de noviembre de 2013, considerando $6^{\circ}$. 
"si una sentencia de divorcio dictada en un pais extranjero se fundamenta en circunstancias que la ley chilena no acepta como causales para decretarlo, resulta contraria a las leyes de la República y se opone al orden público chileno"182.

b) Segundo motivo: "Que tampoco se opongan a la jurisdicción nacional".

El segundo motivo recogido en el artículo 245 CPC. refiere a la no oposición a la jurisdicción nacional. Estamos de nuevo ante una causal que no encuentra parangón en la normativa de origen estatal o convencional aplicable en Chile en relación al reconocimiento y ejecución de sentencias extranjeras. El artículo $423 \mathrm{CDOP}$. refiere con claridad a la necesidad de que el juez de origen de la decisión "tenga competencia para conocer del asunto y juzgarlo, de acuerdo con las reglas de este Código", y el artículo 20 c) del "Acuerdo sobre cooperación y asistencia jurisdiccional del MERCOSUR" exige que las sentencias y laudos extranjeros "emanen de un órgano jurisdiccionalo arbitral competente, según las normas del Estado requerido sobre jurisdicción internacional".

La oposición a "la jurisdicción nacional" deviene así un motivo singular que plantea como primera cuestión la determinación de su exacto significado. Y que una vez más, al igual que ocurre con el motivo recogido en el $\mathrm{N}^{\circ} 1$ del artículo 245 CPC., da lugar a una jurisprudencia por parte de la Corte Suprema que no resulta homologable con la práctica comparada en relación con este punto.

Una lectura del precepto nos conduciría a entender que su tenor esconde una referencia a la comprobación de la competencia del juez de origen ${ }^{183}$. Justo lo que pretenden los mencionados artículos 423 CDIP. y 20 c) del "Acuerdo sobre cooperación y asistencia jurisdiccional del MERCOSUR". Esta idea, además, subyace en algunas decisiones aisladas de la Corte Suprema referidas generalmente al ámbito de la contratación internacional. Así ocurre, por ejemplo, en la sentencia de la Corte Suprema de 14 de mayo de 2007, en el que, entre otros extremos, se valora, y se admite por ese tribunal, la validez del sometimiento a la jurisdicción de los tribunales del Estado de Nueva York: "En cuanto al aspecto relativo a la jurisdicción aplicable, los términos acordados, más que aceptación a someterse exclusivamente a los tribunales estadounidenses, constituye un reconocimiento expreso del derecho de opción a las partes de recurrir a sistemas jurisdiccionales de diferentes paises, entre ellos el de la República de Chile, puesto que expresamente lo señala de esta forma el

\footnotetext{
${ }^{182}$ La sentencia de la Corte Suprema de 2 de junio de 2014, considerando $7^{\circ}$. En idéntico sentido, Corte Suprema, 14 de mayo de 2012, considerando $6^{\circ} ; 27$ de enero de 2014, considerando $7^{\circ}$, o 26 de mayo de 2014, considerando $7^{\circ}$.

${ }^{183}$ Algo que rechaza algún sector doctrinal. Por ejemplo, GuZmán Latorre, D., cit. (n. 27), p. 584.
} 
párrafo consignado en la parte final del acápite anterior, con lo cual permite a las partes y especialmente al banco acreedor, recurrir ante los tribunales de Estados Unidos, tanto del Estado de Nueva York, como de cualquier otro estado de la Unión, en su sistema estadual o federal, pero además, ante 'cualquier otra jurisdicción competente" 184 . Se reconoce así de forma expresa que "debe insistirse en señalar que nuestro legislador ha reconocido la posibilidad de someterse a la jurisdicción de otros paises bajo ciertas condiciones en relación a la materia, las personas y carácter de los tribunales llamados a resolver"185.

Esta aproximación centra el debate sobre el entendimiento del significado del artículo 245 inciso $2^{\circ} \mathrm{CPC}$. en los términos de valorar la competencia del juez de origen de la decisión cuyo exequatur se pretende. Así, y en plena coherencia con ello, la Corte Suprema insiste en esta interpretación de valoración de la competencia del juez de origen, considerando que en el ámbito de la contratación internacional queda claro que "fueron pronunciadas por el tribunal al cual las partes decidieron someter, expresamente, sus dificultades de acuerdo con la cláusula tercera del contrato de garantía suscrito el 12 de marzo de 1998y, las estipulacionespactadas en contratos internacionales que someten sus efectos a una legislación extranjera y otorgan competencia a tribunales foráneos, no hacen más que representar una manifestación de la autonomía de la voluntad absolutamente lícita en nuestra legislación"186. Y esto, además, sería

${ }^{184}$ Considerando $36^{\circ}$.

${ }^{185}$ Considerando $39^{\circ}$. Y añade: “[...] en este sentido se encuentra dispuesto en el artículo 318 del Código de Derecho Internacional Privado, en la Convención sobre Reconocimiento y Ejecución de las Sentencias Arbitrales Extranjeras, en el Decreto Ley 2349 de 28 de octubre de 1978 y en la Ley 19.971, sobre Arbitraje Comercial Internacional, que entró en vigencia el 29 de septiembre de 2004" (Ibíd.)

${ }^{186}$ Corte Suprema, 11 de mayo de 2009, Considerando 13; el cual añade: "Además, debe tenerse en consideración que nos encontramos frente a lo que la doctrina denomina contratos internacionales, respecto de los cuales la dogmática está acorde en darle validez a las cláusulas en las que se acuerde dar jurisdicción a tribunales extranjeros, y nuestro legislador también reconoce tal posibilidad bajo ciertas condiciones en relación a la materia, las personas y carácter de los tribunales llamados a resolver. En este sentido el Decreto Ley 2349 de 28 de octubre de 1978 resuelve esta cuestión en lo que al sector público se refiere, otorgando eficacia a las convenciones que contienen pactos sobre ello. Además el Código de Derecho Internacional Privado en el artículo 318 también lo acepta, código que si bien fue ratificado con reservas, no es menos cierto que sirve de fundamento para explicar el sentido de las normas que gobiernan la materia. Por otra parte la Ley 19.971, sobre Arbitraje Comercial Internacional, que entró en vigencia el 29 de septiembre de 2004, es decir, con posterioridad a los hechos de esta causa, sin perjuicio de lo cual vale como elemento interpretativo evolutivo, en sus articulos 20,28 y 35, permite el sometimiento a normas de ordenamiento jurídico y sistema jurisdiccional arbitral foráneos, siendo vinculante para las partes que han acordado el compromiso". 
acorde con el mandato del inciso $2^{\circ}$ del artículo 113 CCom. ${ }^{187}$.

En esta misma línea, la sentencia de la Corte Suprema, de 24 de marzo de 2009, referente a la solicitud de exequátur de una decisión extranjera declarando la nulidad de un matrimonio celebrado fuera de nuestras fronteras, procede a plantearse, con más o menos sofisticación, la competencia del juez de origen: "Que conforme al principio de derecho internacional 'Lex locus regit actum', el tribunal naturalmente competente para conocer sobre la existencia de un impedimento dirimente absoluto corresponde a aquél donde se celebró el acto, sin perjuicio de lo dispuesto por el inciso segundo del artículo 80 de la Ley $N^{\circ}$ 19.947, precepto que establece la posibilidad para que un tribunal chileno pueda también declarar la nulidad de un matrimonio celebrado en el extranjero, cuando se hubiere contraido en contravención a lo dispuesto en los artículos 5, 6 y 7 de la misma ley"188.

Lamentablemente, estamos ante casos aislados. La práctica jurisprudencial mayoritaria de la Corte Suprema demuestra que el Alto Tribunal no parece compartir esta posición y, lo que resulta más llamativo, no tener claro que significa y que implica esta oposición a la jurisdicción nacional. La doctrina chilena considera que con este criterio se hace mención al hecho de que la sentencia no fue dictada por un tribunal extranjero, siendo que resultaban competentes los chilenos ${ }^{189}$. Pero tampoco esta interpretación es asumida por la Corte Suprema de forma plena. Ciertamente, este aparente desconocimiento de lo que exactamente cubre este motivo se refleja en la valoración, en algún caso aislado, de la eventual competencia de los tribunales chilenos para conocer del litigio: sólo si éstos no hubieran podido resultar competentes para conocer del litigio planteado ante los tribunales extranjeros, se concederá el exequátur a la decisión foránea ${ }^{190}$. Pero, insistimos, se trata de casos aislados.

Y lo que resulta aún más preocupante, se manifiesta en la tendencia a no fundamentar la no oposición a la jurisdicción nacional ${ }^{191}$, o a cotejar de forma conjunta la no contrariedad con el derecho sustantivo chileno y con la jurisdicción nacional. Dos motivos radicalmente diferentes que se recogen, además, en acápites distintos del artículo 245 CPC. y que, sin embargo, se

${ }^{187}$ Véase la sentencia de la Corte Suprema de 10 de julio de 2008, considerando $5^{\circ}$. Resulta significativo que se haga referencia a un precepto, el artículo 113 CCom., que refiere a la determinación del derecho aplicable y no a la concreción de los tribunales competentes para conocer de un litigio.

${ }^{188}$ Considerando $8^{\circ}$.

${ }^{189}$ GuZMán Latorre, D., cit. (n. 27), p. 584.

${ }^{190}$ Corte Suprema, 25 de marzo de 2008 , considerando $7^{\circ}$ o 14 de diciembre de 2006, considerando $5^{\circ}$.

${ }^{191}$ Corte Suprema, 2 de julio de 2014, considerando $8^{\circ}$. 
entienden como equivalentes defacto. De hecho, la antes citada sentencia de la Corte Suprema de 24 de marzo de 2009 referente a la solicitud de exequátur de una decisión extranjera de nulidad afirma: "Que, por lo antes razonado en los motivos precedentes, resulta que la sentencia cuyo exequátur se solicita, no contraviene las leyes de la República, ni tampoco se opone a la jurisdicción nacional, en la medida que significa la disolución del vinculo matrimonial por una causa prevista por nuestro ordenamiento jurídico, según la normativa actualmente vigente, $[. . .]^{\prime 192}$.

Resulta así muy habitual incorporar una regla de estilo que señala que la decisión extranjera "no contraviene las leyes de la República ni tampoco se opone a la jurisdicción nacional" ${ }^{193}$, prosiguiendo seguidamente con la valoración del motivo $1^{\circ}$ del artículo $245 \mathrm{CPC}$. -el relativo a la contrariedad con la ley chilena- y privando, como regla general, de cualquier relevancia o sustantividad propia al motivo $2^{\circ}$ del mencionado precepto -el referente a la oposición a la jurisdicción nacional-. Así, por ejemplo, en un supuesto de solicitud de exequátur de una decisión argentina de interdicción, la Corte Suprema no duda en afirmar que ésta "tampoco se opone a la jurisdicción nacional, en la medida que significa dotar a quien no puede dirigirse a si mismo o administrar competentemente sus negocios, y que no se encuentra bajo potestad alguna de la debida protección"194.

En otras ocasiones, por el contrario, la no oposición a la jurisdicción nacional se ve atribuida una cierta independencia respecto de la no contrariedad con la legislación chilena, aunque en la práctica, se tiende a referir la mencionada no oposición al contenido sustantivo de la decisión y no a norma alguna de competencia judicial internacional. Así, y a modo de ejemplo, en un supuesto en el que se pide la concesión del exequátur respecto de una sentencia extranjera sobre custodia compartida y régimen de visita, resuelto por la sentencia de la Corte Suprema de 10 de mayo de 2010, se afirma que la decisión extranjera "no se opone a la jurisdicción nacional, ya que se trata de

${ }^{192}$ Corte Suprema, 2 de julio de 2014 , considerando $10^{\circ}$. En igual sentido, la sentencia de la Corte Suprema de 2 de julio de 2014, considerando $7^{\circ}$.

${ }^{193}$ Corte Suprema, 2 de abril de 2007. En el mismo sentido, y entre otras muchas, véanse las sentencias de la Corte Suprema de 5 de diciembre de 2001, considerando $7^{\circ}$; de 3 de julio de 2008 , considerando $7^{\circ}$; de 18 de agosto de 2008 , considerando $7^{\circ}$; de 26 de febrero de 2009 , considerando $8^{\circ}$; de 1 de abril de 2009 , considerando $8^{\circ}$ o de 7 de noviembre de 2013, considerando $4^{\circ}$; de 17 de junio de 2013 , considerando $8^{\circ}$.

${ }^{194}$ Corte Suprema, 9 de noviembre de 2011 , considerando $6^{\circ}$. La solución resulta especialmente llamativa dado que en este supuesto se procedió a aplicar el artículo 423 CDIP. lo que, atendido al tenor del artículo 242 CPC. no permite la aplicación del artículo 245 CPC. en el que se recoge esta exigencia de no contravenir las leyes de la República. Similar solución se alcanza en la sentencia de la Corte Suprema de 18 de abril de 2011, considerando $4^{\circ}$. 
la aprobación de la separación de común acuerdo de los cónyuges domiciliados a la época de su dictación en Italia, siendo el menor de nacionalidad italiana"195. Mientras que en otra ocasión, respecto de una decisión de similar naturaleza, la verificación de la eventual oposición a la jurisdicción nacional se ventila señalando una pluralidad de argumentos variados: "En efecto, se opone a la jurisdicción nacional, toda vez que un Tribunal de Familia de la ciudad de Osorno está conociendo de una demanda de relación directa y regular respecto de los menores hijos de las partes de autos, quienes tienen domicilio en Chile y porque la demandada no fue debidamente emplazada de dicha resolución, respectivamente" 196 .

Junto a todo lo anterior, desde la entrada en vigor de la nueva Ley de matrimonio civil se abre un nuevo frente, por decirlo gráficamente, en relación con el mandato del artículo 245 inciso $2^{\circ}$ CPC. La Ley $N^{\circ} 19.947$ dispone en su artículo 87 que: "Será competente para conocer de las acciones de separación, nulidad o divorcio, el juzgado con competencia en materia de familia, del domicilio del demandado". Lógicamente, la ley se refiere a las situaciones estrictamente internas, aquellas que no presentan elementos de internacionalidad, como también lo hace el artículo 5 COT. ${ }^{197}$, el otro precepto utilizado por el Alto Tribunal para justificar su decisión. Frente al mandato del artículo 83 inciso $2^{\circ}$ de la propia ley que precisa que las sentencias extranjeras de divorcio serán reconocidas en Chile de acuerdo con lo dispuesto en el Código de Procedimiento Civil, la Corte Suprema procede a aplicar directamente la regla de competencia judicial interna en el proceso de concesión o denegación del exequátur a las decisiones extranjeras de divorcio. Y así, señala que en atención a "las normas legales mencionadas, no seráposible conceder el exequátur planteado, toda vez que el juicio de divorcio ha debido ser conocido por los tribunales chilenos, conforme lo dispone el artículo $5^{\circ}$ del Código Orgánico de Tribunales en relación con el artículo 87 de la ley 19.947, normas no han sido respetadas en la dictación de la sentencia cuyo cumplimiento se pretende, por cuanto ha sido expedida por un tribunal diverso al del domicilio de la parte demandada, que ha acreditado suficientemente haber mantenido siempre su residencia en el territorio de la República, de manera que se ha visto impedida de hacer valer sus medios de defensa" 198 .

Esta referencia al artículo 5 COT. en combinación, o no, con el artículo

${ }^{195}$ Considerando $5^{\circ}$.

${ }^{196}$ Corte Suprema, 14 de diciembre de 2006, considerando $5^{\circ}$.

197 "A los tribunales mencionados en este artículo corresponderá el conocimiento de todos los asuntos judiciales que se promuevan dentro del territorio de la República, cualquiera que sea su naturaleza o la calidad de las personas que en ellos intervengan, sin perjuicio de las excepciones que establezcan la Constitución y las leyes [...]" .

${ }^{198}$ Corte Suprema, 23 de octubre de 2008, considerando $6^{\circ}$. 
87 de la Ley $\mathrm{N}^{\circ} 19.947$, se asienta, también, en el mandato del artículo 14 CC ., donde se dispone que: "La ley es obligatoria para todos los habitantes de la República, inclusos los extranjeros" 199 . En consonancia con esta interpretación, el carácter obligatorio de la ley chilena implicaría que de "acuerdo con los artículos 134 y siguientes del Código Orgánico de Tribunales y teniendo en consideración que la ley chilena es obligatoria para todos los habitantes de la República, los tribunales del pais son las únicos competentes para pronunciarse sobre la materia. Por consiguiente, no puede sino concluirse que carece de mayor relevancia la circunstancia que la ley sueca pueda otorgar competencia para conocer un asunto de esta naturaleza a sus tribunales, puesto que en la legislación patria no existe ninguna norma que haga primar la aplicación de la ley de dicho pais en este tipo de asuntos, sobre todo si se tiene presente que la demandada, en el curso del juicio de divorcio, reclamó en las instancias pertinentes, la incompetencia del dicho tribunal, por lo que no puede entenderse prorrogada la competencia al Juzgado que determina el estatuto personal del cónyuge demandante, ni expresa ni tácitamente" ${ }^{200}$. En otras palabras, "de lo anterior se concluye que la resolución pronunciada por el referido tribunal del Reino de Suecia, no puede cumplirse en Chile, ya que en la especie no concurre la exigencia segunda del artículo 245 del Código de Procedimiento Civil, cual es, que no se oponga a la jurisdicción nacional" ${ }^{201}$.

c) Tercer motivo: "Quela parte en contra de la cualse invoca la sentencia haya sido debidamente notificada de la acción. Con todo, podrá ella probar que, por otros motivos, estuvo impedida de hacer valer sus medios de defensa".

La sentencia extranjera cuya eficacia se pretende lograr en Chile ha de haber sido dictada asegurando a las partes el derecho a la tutela efectiva. Para ello, el tercer motivo recogido en el artículo 245 CPC. refiere a la exigencia de que la acción ejercitada haya sido debidamente notificada a la parte contra la cual se invoca la sentencia.

Este motivo ha sido considerado en diversas ocasiones en la práctica jurisprudencial chilena. La Corte Suprema señala al abordarlo que esta exigencia de notificación "debe entenderse en concordancia con las disposiciones y principios constitucionales previstos en el articulo $19 N^{\circ} 2$ y $N^{\circ} 3$ de la Carta Politica de la República, los que permiten extraer directrices fundamentales del debido proceso, el que ha venido a transformarse, con el transcurso del tiempo, en simbolo de la garantía judicial en si misma. La garantía del debido proceso consiste, como principio esencial, en no ser privado de la vida, libertad o propiedad sin la garantía que supone la tramitación de un debido proceso, pero

\footnotetext{
${ }^{199}$ Corte Suprema, 24 de julio de 2006, considerando $4^{\circ}$.

${ }^{200}$ Corte Suprema, 24 de julio de 2006, considerando $5^{\circ}$.

${ }^{201}$ Corte Suprema, 24 de julio de 2006, considerando $6^{\circ}$.
} 
no cualquier proceso, sino como destaca la Constitución de Chile, 'racional y justo'"202. Unos adjetivos que deberán referirse de un proceso determinado y no valorarse "de una manera genérica" ${ }^{203}$. El artículo 245 inciso $3^{\circ} \mathrm{CPC}$., afirma la sentencia: "apunta a la esencialidad del derecho a la jurisdicción y al debido proceso, que no solamente la legislación internacional, sino la normativa constitucionaly legal identifican con ciertas garantias, sin las que deja de ser un proceso propiamente tal" 204 . Lo que "ha de trocarse en la certidumbre de que realmente el contenido de la demanda fue noticiado al perseguido, en términos que se encuentre en situación de comprenderlo y de reaccionar ante él"205.

¿Cuándo se entiende que se ha producido una notificación debida? Sería la pregunta que directamente plantea el artículo 245 inciso $3^{\circ} \mathrm{CPC}$.: cuando se demuestre de forma clara y evidente, que se ha sido "real y efectivamente emplazado a la causa". Se trata de que el demandado haya sido emplazado pero a la vez, "en el hecho 'cierto' de haber tomado conocimiento de la acción deducida en su contra, experiencia real y efectiva que no puede satisfacerse con la sola notificación ficta de la demanda"206.

Ello significa que en un proceso en el que la sentencia consigna la rebeldía del demandado ${ }^{207}$, sin que se demuestre la efectiva notificación de la demanda presentada contra él, la normativa extranjera que se encontraría satisfecha en materia de notificaciones ni la forma en que se verificó la aparente notificación, se considere que el requisito del artículo 245 inciso $3^{\circ} \mathrm{CPC}$. no se ha satisfecho y se deniegue el exequátur solicitado ${ }^{208}$. En otras ocasiones, sin embargo, se rechazan las alegaciones formuladas por entender, tras analizar el iter procedimental, "que existió un emplazamiento eficaz como también una válida notificación de la demanda, no observándose conculcación alguna al debido proceso" 209 .

La ausencia o existencia de notificación válida ha sido estimada en algunos

${ }^{202}$ Corte Suprema, 14 de mayo de 2007 , considerando $24^{\circ}$ y de 8 de noviembre de 2011, considerando $8^{\circ}$.

${ }^{203}$ Corte Suprema, 14 de mayo de 2007 , considerando $24^{\circ}$ y de 8 de noviembre de 2011, considerando $8^{\circ}$.

${ }^{204}$ Corte Suprema, 14 de agosto de 2003, considerando $3^{\circ}$ DEG. La Corte Suprema añade que: "Entre tales garantías se comprende la de la audiencia o emplazamiento, que requiere, en primer término, del hecho irrenunciable de haberse puesto la pretensión judicial en conocimiento de la persona contra la que se dirige y, en segundo término, de un periodo destinado a que esta manifieste su parecer sobre el requerimiento".

${ }^{205}$ Corte Suprema, 14 de agosto de 2012, considerando $4^{\circ}$ DEG.

${ }^{206}$ Corte Suprema, 8 de noviembre de 2011, considerando $9^{\circ}$.

${ }^{207}$ Sobre la rebeldía, nótese la sentencia de la Corte Suprema de 14 de agosto de 2012, considerandos $3^{\circ}$ DEG y $4^{\circ}$ DEG

${ }^{208}$ Corte Suprema, 8 de noviembre de 2011, considerando $11^{\circ}$.

${ }^{209}$ Corte Suprema, 11 de mayo de 2009, considerando $15^{\circ}$. 
casos por la Corte Suprema de Chile. En ocasiones, de forma lineal y sin mayor debate ${ }^{210}$, y en otros a través de la verificación ${ }^{211}$ o no ${ }^{212}$ de su existencia.

d) Cuarto motivo: "Que estén ejecutoriadas en conformidad a las leyes del pais en que hayan sido pronunciadas".

El cuarto motivo que debe cumplirse con vistas a conceder el exequátur a la decisión foránea refiere a la necesidad de que la decisión cuya eficacia se pretende esté ejecutoriada en conformidad a las leyes del país en que hayan sido pronunciadas: la doctrina chilena es clara al afirmar que "sería absurdo poder cumplir la sentencia en Chile, y no en el lugar de donde procede"213. La Corte Suprema considera que la "constatación que una sentencia se encuentra ejecutoriada, se ha declarado por esta Corte, que corresponde cumplirla de acuerdo a las leyes procesales del Estado requirente, por lo que resultapertinente entenderla con cierta latitud, en el sentido que se ejercieron los recursos legales o que ya no es posible deducir nuevas impugnaciones, sin que sea preciso e indispensable que se acredite conforme a los términos del artículo 174 del Código de Procedimiento Civil"214.

La cuestión de la naturaleza ejecutoria de la decisión extranjera plantea directamente la condición de la decisión cuya eficacia se pretende en Chile, algo que ya ha sido avanzado con anterioridad ${ }^{215}$. El carácter ejecutorio no depende necesariamente de la firmeza de la decisión. Puede darse el caso de una decisión extranjera susceptible de recurso en el país de origen, que sin embargo sea plenamente ejecutoria allí. De hecho, todo el modelo de reconocimiento y ejecución europeo se sustenta sobre esta posibilidad ${ }^{216}$. La doctrina chilena, empero, parece apostar por una noción expansiva de ejecutoriedad refiriéndola a aquellas decisiones que siendo ejecutorias en su país de origen son, también, firmes ${ }^{217}$.

La causa ha sido alegada en varias ocasiones ante la Corte Suprema de Justicia, entendiéndose en la mayoría de ellas que la decisión foránea se en-

${ }^{210}$ Corte Suprema, 14 de diciembre de 2006, considerando $5^{\circ}$, en la que se considera que no hubo notificación válida.

${ }^{211}$ Corte Suprema, 24 de enero de 2005, considerando $5^{\circ}$ o de 25 de marzo de 2008, considerando $9^{\circ}$, en las que se consideran probadas la notificación personal al demandado.

${ }^{212}$ Corte Suprema, 24 de noviembre de 2011, considerando $4^{\circ}$.

${ }^{213}$ GuZmán Latorre, D., cit. (n. 27), p. 585.

${ }^{214}$ Corte Suprema 14 de mayo de 2007, considerando $20^{\circ}$.

${ }^{215}$ Véase el cap. III, $4 c$ ).

${ }^{216}$ Véase: IgLesias Buhigues, J. L., cit. (n. 41), p. 204.

${ }^{217}$ Véase: GuZmán Latorre, D., cit. (n. 27), p. 585. 
cuentra ejecutoriada ${ }^{218}$, y considerándose que no cuenta con tal condición en tan sólo algunos casos aislados ${ }^{219}$.

\section{Otras causas no previstas en el articulo 245 CPC.}

Junto a las cuatro causas previstas explícitamente en el artículo 245 CPC., predominantes -como hemos visto- incluso en aquellas ocasiones en que resulta de aplicación los posibles convenios aplicables en la materia, la práctica de la Corte Suprema de Justicia refleja la presencia de todo un conjunto de causas alegadas por las partes y que carecen de sustento legal. Causas de distinta naturaleza, algunas de las cuales serían susceptibles de incluirse bajo el mandato genérico de la contrariedad con el orden público internacional chileno, caso de existir éste. Se alegan así, con escaso éxito, motivos tales como: i) La existencia de cosa juzgada ${ }^{220}$; ii) la existencia de una previa sentencia en Chile sobre la materia ${ }^{221}$; iii) la existencia de un breve plazo para contestar a la demanda ${ }^{222} ; i v$ ) la existencia de un breve plazo para contratar un abogado para defender los intereses de la parte ${ }^{223} ; v$ ) la imposibilidad de ejercer el derecho de defensa ${ }^{224} ; v i$ ) el hecho de no asegurarse el debido proceso ${ }^{225} ;$ vii) el tratarse de una sentencia puramente declarativa ${ }^{226}$; viii) el hecho de haber caducado el plazo de ejecutividad ${ }^{227} ; i x$ ) la ausencia de personería legal por parte del abogado de la parte ${ }^{228} ; x$ ) la ausencia genérica de personería ${ }^{229} ; x i$ ) la falta de legitimidad activa $\left.{ }^{230} ; x i i\right)$ el hecho de que el instrumento extranjero cuya eficacia se pretende en Chile no es una sentencia ${ }^{231}$; xiii) la falta de

${ }^{218}$ Corte Suprema, 21 de marzo de 2001, considerando $9^{\circ} ; 8$ de octubre de 2003, considerando $4^{\circ} ; 24$ de enero de 2005 , considerando $10^{\circ} ; 25$ de marzo de 2008 , considerando $10^{\circ}$; 11 de mayo de 2009 , considerando $16^{\circ}$.

${ }^{219}$ Corte Suprema, 4 de mayo de 2007, considerando $20^{\circ}$ o 28 de diciembre de 2000 considerando $6^{\circ}$ (último considerando numerado en la sentencia erróneamente como $3^{\circ}$ ).

${ }^{220}$ Corte Suprema, 9 de noviembre de 2006, considerando $5^{\circ}$ o 4 de mayo de 2007, considerando $42^{\circ}$.

${ }^{221}$ Corte Suprema, 17 de junio de 2013.

${ }^{222}$ Corte Suprema, 24 de enero de 2005 , considerando $4^{\circ}$.

${ }^{223}$ Corte Suprema, 24 de enero de 2005, considerando $4^{\circ}$.

${ }^{224}$ Corte Suprema, 25 de marzo de 2008, considerando $9^{\circ}$.

${ }^{225}$ Corte Suprema, 11 de mayo de 2009, considerando $12^{\circ}$; de 4 de mayo de 2007, considerandos $21^{\circ}$ a $24^{\circ}$ o 21 de enero de 2008 , considerando $12^{\circ}$.

${ }^{226}$ Corte Suprema, 4 de mayo de 2007 , considerandos $18^{\circ}$ y $19^{\circ}$.

${ }^{227}$ Corte Suprema, 4 de mayo de 2007, considerando $43^{\circ}$.

${ }^{228}$ Corte Suprema, 24 de enero de 2005 , considerando $3^{\circ}$.

${ }^{229}$ Corte Suprema, 11 de mayo de 2009, considerando $9^{\circ}$; de 14 de mayo de 2007 considerando $13^{\circ}$ y 21 de enero de 2008 , considerando $9^{\circ}$.

${ }^{230}$ Ibíd.

${ }^{231}$ Corte Suprema, 4 de mayo de 2007 , considerandos $16^{\circ}$ y $17^{\circ}$. 
autenticidad de los documentos presentados $\left.{ }^{232} ; x i v\right)$ la contradicción con el artículo $16 \mathrm{CC}$ por pretenderse embargo de bienes sitos en Chile ${ }^{233} ; x v$ ) la existencia de un matrimonio que ya fue anulado en Chile con anteriori$\left.\mathrm{dad}^{234} ; x v i\right)$ la muerte presunta de una de las parte $\left.{ }^{235} ; x v i i\right)$ no dar cuenta de la obligación invocada ${ }^{236}$; xviii) la extinción de la obligación que se pretende cumplir $\left.{ }^{237} ; x i x\right)$ la prescripción de la obligación que se pretende cumplir ${ }^{238}$; $x x$ ) la obligación de pagar impuesto y no ser por ello título ejecutivo $\left.{ }^{239} ; x x i\right)$ el hecho de no haber sido juzgado por un tribunal imparcial ${ }^{240} ; y$, por último, y significativamente, xxiii) la contrariedad con el orden público ${ }^{241}$.

\section{EL PROCEDIMIENTO DE EXEQUÁTUR PREVISTO EN EL "Código de Procedimiento Civil"}

Para concluir, y en línea con el mandato del artículo 242 CPC., en aquellas ocasiones en que exista un texto convencional que vincule a Chile en esta materia, se estará a lo dispuesto en él, procediéndose a aplicar los preceptos del Código de Procedimiento Civil en el supuesto de su ausencia.

\section{Procedimiento de exequátur en supuestos de régimen convencional.}

Como se ha apuntado anteriormente, el régimen convencional en relación con las resoluciones judiciales extranjeras - no así, recordemos, con las arbitrales- implica de facto una referencia al Código de Derecho Internacional Privado, el denominado "Código Bustamante" de 1928 y, en menor medida, al Acuerdo de cooperación y asistencia jurisdicción en materia civil, comercial, laboral y administrativa entre los Estados partes del Mercosur y la República de Bolivia y la República de Chile.

Por su propia naturaleza, y a diferencia de lo que ocurre, por ejemplo, en el ámbito de las sentencias arbitrales, donde el procedimiento de exequátur queda referido a lo dispuesto en la normativa procesal del país donde se solicita el exequatur ${ }^{242}$, el "Código Bustamante" establece un procedimiento específico,

${ }^{232}$ Corte Suprema, 11 de mayo de 2009, considerando $11^{\circ}$ y de 14 de mayo de 2007 considerando $15^{\circ}$.

${ }^{233}$ Corte Suprema, 21 de marzo de 2001, considerando $8^{\circ}$.

${ }^{234}$ Corte Suprema, 22 de marzo de 2000.

${ }^{235}$ Corte Suprema, 31 de enero de 2011.

${ }^{236}$ Corte Suprema, 30 de septiembre de 2008.

${ }^{237}$ Corte Suprema, 4 de mayo de 2007, considerando $44^{\circ}$.

${ }^{238}$ Corte Suprema, 21 de enero de 2008, considerando $14^{\circ}$.

${ }^{239}$ Corte Suprema, 24 de enero de 2005 , considerandos $8^{\circ}$ y $9^{\circ}$.

${ }^{240}$ Corte Suprema, 25 de marzo de 2008, considerando $8^{\circ}$.

${ }^{241}$ Corte Suprema, 4 de mayo de 2007, considerando $25^{\circ}$.

${ }^{242}$ Nótense los artículos 4, de la Convención interamericana sobre arbitraje comercial 
aplicable a aquellas resoluciones que entren en su ámbito de aplicación. Un modelo que se sustenta en lo dispuesto en la "legislación interior" -artículo 424 CDIP.- pero que en la práctica, al menos en el caso de Chile, introduce interesantes modificaciones respecto de éste ${ }^{243}$.

De esta forma, el artículo 424 CDIP. afirma como regla general que la "ejecución de la sentencia deberá solicitarse del juez o tribunal competente para llevarla a efecto, previas las formalidades requeridas por la legislación interior". De nuevo, y al igual que ocurre en el Código de Procedimiento Civil se habla tan sólo de ejecución, no de reconocimiento de resoluciones extranjeras, obviando la diferencia entre ambas figuras, aunque como ya se ha apuntado anteriormente el artículo 431 CDIP. asume la existencia de resoluciones que no son susceptibles de ejecución.

El juez o tribunal a quien se solicite la ejecución "oirá antes de decretarlao denegarla, y por término de 20 dias, a la parte contra quien se dirija y al Fiscal o Ministerio Público"244. Dicha citación se practicará mediante exhorto o comisión rogatoria de acuerdo a lo previsto en el propio Código, si no cuenta con domicilio en Chile y careciere de representación bastante o en la forma establecida en la legislación chilena si cuenta con éste ${ }^{245}$. Si dicha parte no comparece, el procedimiento avanzará sin más ${ }^{246}$. El juez o tribunal podrá denegar el cumplimiento, devolviendo la documentación presentada ${ }^{247}$. $\mathrm{O}$ concederla, en cuyo caso la ejecución se ajustará a lo dispuesto en la legislación “del juez o tribunales para sus propios fallos" ${ }^{248}$. En todo caso, se otorgarán todos los recursos que la ley del Estado conceda en los términos fijados por el Código ${ }^{249}$.

Por su parte, el artículo 24 del "Acuerdo del Mercosur" declara de forma explícita que los "procedimientos, incluso la competencia de los respectivos órganos jurisdiccionales, a los efectos de reconocimiento y ejecución de las sentencias o de los laudos arbitrales, se regirán por la ley del Estado requerido". Esto es, por los mandatos del artículo 247 ss. CPC.

internacional ó 3 del "Convenio de Nueva York" de 1958 Sobre reconocimiento y ejecución de sentencias arbitrales extranjeras.

${ }^{243} \mathrm{El}$ modelo, al igual que ocurre en el Código de Procedimiento Civil, es aplicable tanto a las sentencias judiciales como a las arbitrales (artículo 432 CDIP.)

${ }^{244}$ Artículo 426 CDIP.

${ }^{245}$ Artículo 427 CDIP. El precepto habla del Estado requerido. A efectos de focalizarnos en Chile, lo convertimos en una referencia al ordenamiento jurídico chileno.

${ }^{246}$ Artículo 428 CDIP.

${ }^{247}$ Artículo 429 CDIP.

${ }^{248}$ Artículo 430 CDIP.

${ }^{249}$ Artículo 425 CDIP. 
2. Procedimiento de exequátur en supuestos de ausencia de régimen convencional.

El procedimiento para solicitar el reconocimiento y ejecución viene recogido en los artículos 247 a 250 CPC. Como punto de partida, el artículo 247 CPC. establece la competencia de la Corte Suprema para conocer del procedimiento de exequátur. A ella deberá presentarse "la resolución que se trate de ejecutar [...] en copia legalizada"250.

La Corte Suprema tiene ante sí dos posibles situaciones, dependiendo de la naturaleza de la sentencia extranjera cuyo exequátur se solicita:

i) En primer lugar -opción prevista en el artículo 248 CPC. -, y en relación con "casos de jurisdicción contenciosa", entendiendo este término en el sentido de proceso con contradicción independientemente de la naturaleza de la resolución dictada "se dará conocimiento de la solicitud a la parte contra quien se pide la ejecución, la cual tendrápara exponer lo que estime conveniente un término igual al de emplazamiento para contestar demandas" 251.

ii) En segundo lugar -opción prevista en el artículo 249 CPC.--y respecto de los asuntos de "jurisdicción no voluntaria", entendiendo como tales los conocidos en procesos sin contradicción, "el tribunal resolverá con sólo la audiencia del fiscal judicial".

El artículo $248 \mathrm{CPC}$. incorpora en su apartado $2^{\circ}$ una regla que no aparece prevista en el artículo 249 CPC. precitado y que afirma que, "Con la contestación de la parte o en su rebeldia, y con previa audiencia del fiscal judicial, el tribunal declarará si debe o no darse cumplimiento a la resolución". La referencia que realiza el artículo 249 CPC. a la posibilidad de "resolver" debe interpretarse en este mismo sentido de declarar si debe, o no, darse cumplimiento a la resolución cuyo exequátur se solicita.

En todo caso, y ésta es una opción que por su localización en el articulado del Código de Procedimiento Civil pareciera reputable de las dos posibilidades previstas -casos contenciosos y no contenciosos- si el tribunal lo estimara

${ }^{250}$ Véase: GuZmán LATORRE, D., cit. (n. 27), p. 573, en relación con las personas legitimadas para ejercitar la denominada acción de exequátur

${ }^{251}$ En relación con este precepto, véase: la sentencia de la Corte Suprema de 22 de noviembre de 2006, considerando Undécimo. Resulta igualmente interesante la sentencia de la Corte Suprema de 24 de marzo de 2009, en la que se alega litispendencia a la hora de oponer la eficacia de la decisión extranjera sobre nulidad de matrimonio en Chile: "Que en efecto el procedimiento de exequátur constituye un trámite o gestión que, cuando se acoge, constituye una autorización que se le da a una sentencia extranjera, para que pueda cumplirse en Chile, en el caso de cumplirse los requisitos legales previstos para tales efectos por el ordenamiento jurídico. Por lo tanto, no corresponde su naturaleza a la de un juicio o litis propiamente tal, donde se ejerza una acción respecto de la cual pueda deducirse alguna oposición como la planteada, de manera tal que no resulta procedente promover ni tampoco resolver la excepción en comento" (considerando $2^{\circ}$ ). 
necesario, "podrá abrir un término de prueba antes de resolver, en la forma y por el tiempo que este Código establece para los incidentes". Cuales sean los motivos que justifiquen esta actuación es algo a determinar exclusivamente por el tribunal, sin que se nos aporte indicación adicional alguna. Este precepto ha sido objeto de valoración por parte del Tribunal Constitucional, que ha avalado su constitucionalidad ${ }^{252}$.

En el supuesto de que se decida por la Corte Suprema que debe “darse cumplimiento a la resolución" 253 extranjera cuyo exequátur se solicitó. Esto es, "Mandada cumplir una resolución pronunciada en pais extranjero" -en terminología del artículo 251 CPC.- “[...] sepedirá su ejecución al tribunal a quien habria correspondido conocer del negocio en primera o en única instancia, si el juicio se hubiera promovido en Chile"254.

A diferencia de lo que hace el Código de Derecho Internacional Privado, el Código de Procedimiento Civil nada señala sobre la posibilidad de recurrir la decisión de concesión o denegación del exequátur y la jurisprudencia existente en la materia resulta irrelevante ${ }^{255}$.

\section{A MODO DE CONCLUSIÓN Y PROPUESTA}

El modelo chileno de reconocimiento y ejecución de resoluciones judiciales extranjeras se caracteriza por la coexistencia de unos textos normativos escasamente elaborados -sobre todo el Código de Procedimiento Civil-y alejados de los lineamientos mayoritarios existentes en el plano comparado en la materia. Y de una práctica jurisprudencial tan amplia como maximalista y poco elaborada en sus soluciones, amén de paupérrima desde un punto de vista argumentativo y dogmático. Una práctica jurisprudencial que lejos de colmar las lagunas y zonas oscuras que presenta la arcaica legislación nacional en la materia, no hace sino agravar en unos casos sus incoherencias -la relación entre el tenor de la decisión extranjera y el derecho chileno es buen ejemplo de ello-o desatender, en otros, sus mandatos -la prevalencia de la norma del artículo 245 CPC. sobre la regla del artículo 242 CPC. resulta igualmente llamativa-. El resultado final no puede resultar más decepcionante y a la vez más preocupante, poniendo de relieve una falta clamorosa de seguridad jurídica en todo el modelo, y en su operar, que afecta directa y negativamente a las expectativas jurídicas de los justiciables. Lo anterior, por desalentador

${ }^{252}$ Sentencia del Tribunal Constitucional, de 4 de junio de 2006.

${ }^{253}$ Artículo 249 inciso $2^{\circ}$ CPC.

${ }^{254} \mathrm{Al}$ respecto, véase la sentencia de la Corte Suprema de 27 de marzo de 2006. Sobre la naturaleza de esta decisión, véase: Guzmán Latorre, D., cit. (n. 27), pp. 575-576.

${ }^{255}$ Corte Suprema, 22 de octubre de 2001. 
que pueda parecer, no deja de constituir un llamado al legislador en favor de una reforma urgente del modelo de reconocimiento y ejecución de resolución judiciales extranjeras en la República. Un país como Chile, abierto como ningún otro en Iberoamérica al mundo, no se merece un sistema de homologación y ejecución de sentencias foráneas como el actualmente existente.

\section{BIBLIOGRAFÍA}

Esplugues Mota, C., El Derecho internacional privado: caracteristicas generales, en Esplugues Mota, C. - Iglesias Buhigues, J. L. - Palao Moreno, G., Derecho internacional privado (8a edición, Valencia, Tirant lo Blanch, 2014).

Esplugues Mota, C., La determinación del Derecho aplicable a las situaciones jurídicoprivadas internacionales: aplicación práctica de la norma de conflicto, en EsPLUGUeS Mota, C. - Iglesias Buhigues, J. L. - Fernández Arroyo, D., Aspectos esenciales de la competencia judicial internacional en vistas de su reglamentación interamericana, en Llanos Mansilla, H. - Picand Albónico, E. (coordinadores), Estudios de derecho internacional. Libro homenaje al profesor Santiago Benadava (Santiago, Librotecnia, 2008).

Esplugues Mota, C., Una aproximación internacional privatista al nuevo código de procedimiento civil de Bolivia, de 2013, en Revista Boliviana de Derecho, 18 (2014).

García Pujol, I., Cumplimiento de sentencias extranjeras en Chile: alejándose del régimen de reciprocidad legal, en Llanos Mansilla, H. - Picand Albónico, E. (coordinadores), Estudios de derecho internacional. Libro homenaje al profesor Santiago Benadava (Santiago, Librotecnia, 2008).

Garcimartin Alférez, F., Derecho internacional privado, (Cizur Menor, Civitas Thomson Reuters, 2012).

GROB DuHALD, F. J., La ley aplicable a los contratos internacionales en ausencia de elección por las partes, en Revista Chilena de Derecho, 41 (2014).

GuZmán LATORRE, D., Tratado de derecho internacional privado (Santiago, Editorial Jurídica de Chile, 2003).

Hamilton, E., Solución de conflictos de leyes y jurisdicción en Chile (Santiago, Ed. Jurídica de Chile, 1966).

IgLesias Buhigues, J. L., Eficacia extraterritorial de sentencias y documentos públicos extranjeros: el reconocimiento y ejecución de resoluciones judiciales extranjeras y documentos públicos con fuerza ejecutiva, en Esplugues Mota, C. - Iglesias Buhigues, J. L. - Palao Moreno, G., Derecho internacional privado (8a edición, Valencia, Tirant lo Blanch, 2014).

Monsalvez Müller, A, Derecho internacional privado. Parte general (Santiago, Universidad Sek, 2005).

Monsalvez Müller, A., Cumplimiento en Chile de las sentencias dictadaspor tribunales internacionales, en Ius et Praxis, 2 (1997) 2.

Monsalvez Müller, A., Del cumplimiento en Chile de resoluciones pronunciadas por tribunales extranjeros (Santiago, Ed. Andrés Bello, 1973).

Soriano, M. - Garcimartin Alférez, F., Derecho procesal civil internacional. Litigación internacional ( $2^{a}$ edición, Cizur Menor, Civitas - Thomson, 2007). 
